\title{
Human Pluripotent Stem Cells-Based Therapies for Neurodegenerative Diseases: Current Status and Challenges
}

\author{
Elizabeth Ford 1,2,3,+ Jodie Pearlman 1,2,3,+ Travis Ruan 1,2 , John Manion 1,2,4,5, \\ Matthew Waller ${ }^{1,2}$, Gregory G. Neely ${ }^{1,2}$ and Leslie Caron $1,2, *$ (D) \\ 1 Dr. John and Anne Chong Lab for Functional Genomics, Charles Perkins Centre, Centenary Institute, \\ University of Sydney, Camperdown, NSW 2006, Australia; elizabeth.ford@bath.edu (E.F.); \\ jodie.pearlman@bath.edu (J.P.); travis.ruan@sydney.edu.au (T.R.); \\ John.Manion@childrens.harvard.edu (J.M.); matthew.waller@sydney.edu.au (M.W.); \\ greg.neely@sydney.edu.au (G.G.N.) \\ 2 School of Life and Environmental Sciences, University of Sydney, Camperdown, NSW 2006, Australia \\ Department of Biology and Biochemistry, University of Bath, Bath BA2 7AY, UK \\ Department of Urology, Boston Children's Hospital, Boston, MA 02115, USA \\ 5 Departments of Surgery and Microbiology, Harvard Medical School, Boston, MA 02115, USA \\ * Correspondence: leslie.caron@sydney.edu.au; Tel.: +61-2-8627-5619 \\ + These authors contributed equally.
}

Received: 24 October 2020; Accepted: 17 November 2020; Published: 20 November 2020

\begin{abstract}
Neurodegenerative diseases are characterized by irreversible cell damage, loss of neuronal cells and limited regeneration potential of the adult nervous system. Pluripotent stem cells are capable of differentiating into the multitude of cell types that compose the central and peripheral nervous systems and so have become the major focus of cell replacement therapies for the treatment of neurological disorders. Human embryonic stem cell (hESC) and human induced pluripotent stem cell (hiPSC)-derived cells have both been extensively studied as cell therapies in a wide range of neurodegenerative disease models in rodents and non-human primates, including Parkinson's disease, stroke, epilepsy, spinal cord injury, Alzheimer's disease, multiple sclerosis and pain. In this review, we discuss the latest progress made with stem cell therapies targeting these pathologies. We also evaluate the challenges in clinical application of human pluripotent stem cell (hPSC)-based therapies including risk of oncogenesis and tumor formation, immune rejection and difficulty in regeneration of the heterogeneous cell types composing the central nervous system.
\end{abstract}

Keywords: neurodegenerative diseases; human pluripotent stem cells; cell therapy; regenerative medicine

\section{Introduction}

Stem cell biology is indisputably a fast-moving field of research and over the past few years human pluripotent stem cells (hPSC)-based therapies have progressed into early clinical trials, with several patients now receiving hPSC-derived cells. Transplantations of retinal pigmented epithelium (RPE) derived from human embryonic stem cells (hESC) [1-3] and human induced pluripotent stem cells (hiPSC) [4] have been tested in patients with age-related macular degeneration (AMD), a leading cause of blindness among the older population [5] and have shown promising results in stalling disease progression. HiPSC-based therapy for the treatment of Parkinson's disease (PD) entered clinical trials in 2018, almost 30 years after the first transplants of human fetal material revealed the potential for dopaminergic cell transplants [6,7]. In August 2019, a patient in Japan received the 
first corneal transplant made from hiPSC. Although it is still too early to ascertain the efficacy of the procedure, the patient's vision has reportedly improved considerably since the transplantation. Clinical trials using hiPSC to treat spinal cord injury are also about to start in Japan [8]. The remarkable clinical advance that these first-in-human hPSC- based therapies represent has generated considerable excitement. However, ethical and safety concerns associated with hPSC transplantation persist and clinical application of stem cells remains a daunting task. Although a large repertoire of hPSC-derived cell types $(>40)$ can be generated in vitro, each has its own challenges to overcome to be suitable for cell therapy. Regenerative medicine should therefore address pathologies or conditions with unmet medical needs only. Nonetheless, stem cell therapy may represent the most promising approach for a large number of degenerative diseases given the limited capacity of intrinsic tissue regeneration.

Over the past few decades, stem cell therapies have advanced further towards the clinic to treat damaged tissues and various degenerative diseases, especially those affecting the nervous system. Neurodegenerative diseases are frequently characterized by the irreversible functional impairment and/or loss of cells and limited regeneration of the adult nervous system. Cell replacement, therefore, represents a critical strategy for the effective treatment of neurodegenerative diseases. HPSC can be differentiated into many kinds of neuronal cells, from neural progenitors to specialized mature neurons, astrocytes or oligodendrocytes. All have great potential in treating neuropathies such as PD, multiple sclerosis (MS) or spinal cord injury (SCI). Recently, two studies have reported oncogenic mutations in hiPSC [4] and hESC [9] and raised the importance of designing new strategies for safe and efficient production and functional validation of hPSC-derived cells that can be used for transplantation. However, there are still debates as to whether stem cell therapy is feasible, safe and efficient or just conceptual. Considering the rising interest in stem cell-based therapies, a better understanding of their implication in the treatment of neurodegenerative diseases is critical for the design of appropriate strategies. It is therefore both a timely and a necessary question to review the current state of hPSC-based therapies and their relevance in nervous system regeneration. In this review, we discuss the progress made with cellular therapies, where cells derived from hPSC are directly delivered in vivo, in the context of central nervous system (CNS) pathologies. Lastly, we review the challenges of working with hPSC and discuss the hurdles that must be overcome to translate these promising approaches to the clinic for the treatment of neurodegenerative diseases.

\section{Main Text}

\subsection{Parkinson's Disease}

Parkinson's disease (PD) is a progressive neurodegenerative disorder, characterized by a progressive loss of dopaminergic neurons (DANs) within the substantia nigra, subsequently causing bradykinesia, tremor and other debilitating symptoms such as cognitive decline. Therapies that increase dopamine (DA) level in the brain, including the DA precursor L-DOPA (levodopa), and deep brain stimulation are currently the gold standard treatment for PD [10]. Administration of L-DOPA can have dramatic effects on bradykinesia and is often an effective initial treatment to improve the quality of life of some patients. However, as the pathology progresses a decreasing number of dopaminergic neurons are able to convert L-DOPA and fewer synapses are able to release dopamine. Subsequently the treatment loses efficacy[11,12]. Hence, cell replacement of lost DANs for PD has long been pursued and has profound clinical interest.

Whilst human fetal material has long been explored for Parkinson's disease, human embryos are not a viable source of material for cell therapy. Various human stem cell derivatives, the most common being neural stem cells (NSCs) or neural progenitor cells (NPCs) and DANs, have already shown an improvement in symptoms following cell transplantation in rodent and primate PD models (Figure 1, Table 1). 


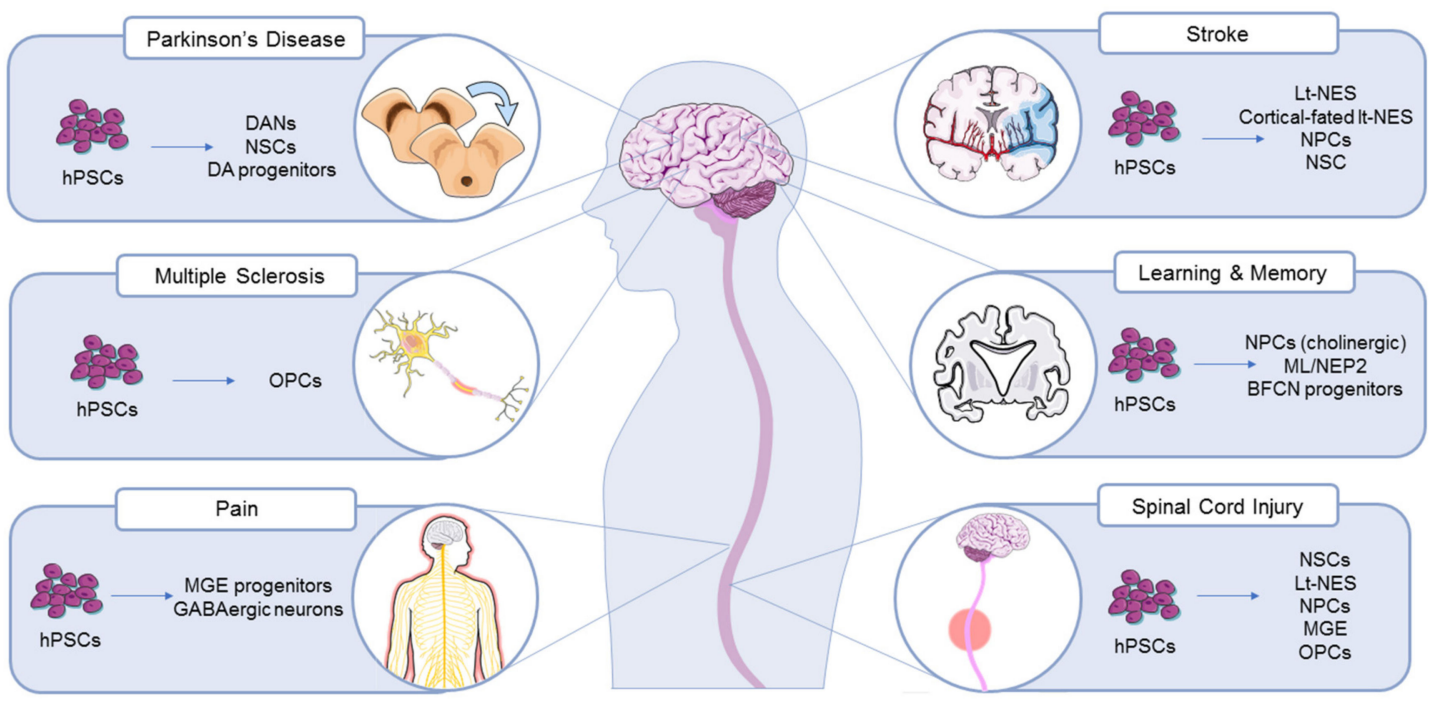

Figure 1. HPSC-based therapies for the treatment of neurodegenerative diseases. An overview of the different cell types generated from hPSC currently being studied and developed as cell therapies for the treatment of various neurodegenerative diseases. 
Table 1. Overview of hPSC-based therapy studies performed in neurodegenerative diseases animal models.

\begin{tabular}{|c|c|c|c|c|c|}
\hline Disease & $\begin{array}{l}\text { Cell Type } \\
\text { Transplanted }\end{array}$ & Transplant Site & Animal Model & Readout & Reference \\
\hline \multirow{11}{*}{ PD } & hESC-DANs & Striatum & Rat, 6-OHDA & $\begin{array}{l}\text { apomorphine-induced rotations, adjusting step test, } \\
\text { cylinder test. }\end{array}$ & [13] \\
\hline & hESC-DANs & $\begin{array}{l}\text { Striatum in mice, } \\
\text { putamen in monkeys }\end{array}$ & $\begin{array}{c}\text { Mouse } \\
\text { Monkeys, MPTP }\end{array}$ & $\begin{array}{l}\text { MRI, Neurological rating scale, video-based analysis } \\
\text { of spontaneous movements }\end{array}$ & [14] \\
\hline & hESC-midbrain DANs & $\begin{array}{l}\text { Striatum in mice and rats, } \\
\text { Putamen in monkeys }\end{array}$ & $\begin{array}{l}\text { Mouse, 6-OHDA Rats, 6-OHDA } \\
\text { Monkeys, MPTP }\end{array}$ & $\begin{array}{l}\text { Amphetamine-induced rotations (Rats and mice), } \\
\text { stepping test (rats), cylinder test (rats). }\end{array}$ & [15] \\
\hline & hESC-midbrain DANs & Striatum & Rat, 6-OHDA & $\begin{array}{l}\text { Amphetamine-induced rotation } \\
\text { Cylinder test }\end{array}$ & [16] \\
\hline & hESC-midbrain DANs & Striatum & Rat, 6-OHDA & $\begin{array}{c}\text { MRI } \\
\text { MR spectroscopy } \\
\text { PET-Scan } \\
\text { Amphetamine-induced rotations }\end{array}$ & [17] \\
\hline & hESC-DA progenitor cells & Striatum & $\begin{array}{l}\text { Rat, 6-OHDA } \\
\text { Mouse, 6-OHDA }\end{array}$ & $\begin{array}{l}\text { Amphetamine-induced rotations } \\
\text { Cylinder test }\end{array}$ & [18] \\
\hline & hiPSC-DANs & Striatum & Rat, 6-OHDA & Amphetamine- and apomorphine-induced rotations & [19] \\
\hline & hiPSC-DANs & Striatum & $\begin{array}{l}\text { Rat, 6-OHDA } \\
\text { Mouse, } \alpha \text {-Synuclein Tg }\end{array}$ & Amphetamine-induced rotations & [20] \\
\hline & hiPSC-NSCs & Striatum & Rat, 6-OHDA & $\begin{array}{l}\text { Turning-over test } \\
\text { Rotation-rod test }\end{array}$ & [22] \\
\hline & hiPSC-NPCs & Putamen & Monkey, MPTP & $\begin{array}{l}\text { Raisin pick up test } \\
\text { Neurological rating scale }\end{array}$ & [23] \\
\hline & hiPSC-DA progenitor cells & Putamen & Monkey, MPTP & $\begin{array}{l}\text { Neurological rating scale, } \\
\text { Video-based analysis of spontaneous movements }\end{array}$ & [24] \\
\hline
\end{tabular}


Table 1. Cont

\begin{tabular}{|c|c|c|c|c|c|}
\hline Disease & $\begin{array}{l}\text { Cell Type } \\
\text { Transplanted }\end{array}$ & Transplant Site & Animal Model & Readout & Reference \\
\hline \multirow{9}{*}{ Stroke } & hiPSC-lt-NES cells & Striatum, Cortex & Rat \& Mouse, MCAo & Staircase and corridor tests & [25] \\
\hline & hiPSC-cortical fated lt-NES & Cortex & Rat, MCAo & $\begin{array}{c}\text { Immunoelectron microscopy } \\
\text { Rabies virus retrograde synaptic tracing } \\
\text { electrophysiology }\end{array}$ & [26] \\
\hline & hiPSC-cortical fated lt-NES & Cortex & Rat, MCAo & Cylinder and stepping test & [27] \\
\hline & hiPSC-cortical fated lt-NES & Cortex & Rat, MCAo & $\begin{array}{l}\text { Rabies virus retrograde synaptic tracing } \\
\text { Immunoelectron microscopy } \\
\text { Optogenetics } \\
\text { Electrophysiology } \\
\text { Cylinder test }\end{array}$ & [28] \\
\hline & hiPSC-NPCs & Striatum & Mouse, MCAo & Modified neurological severity score (mNSS) & [29] \\
\hline & hiPSC-NPCs & $\begin{array}{l}\text { Penumbra region of } \\
\text { the cortex }\end{array}$ & Mouse, MCAo & Adhesive removal test - latency and removal time & [30] \\
\hline & hiPSC-NPCs & Striatum & Rat, MCAo & $\begin{array}{c}\text { Rotarod test } \\
\text { Stepping test } \\
\text { mNSS } \\
\text { Apomorphine-induced rotation tests }\end{array}$ & [31] \\
\hline & hiPS-NPCs & Right cortex & $\begin{array}{l}\text { Rat, Incision in common } \\
\text { carotid artery }\end{array}$ & $\begin{array}{l}\text { Vibrissae-elicited forelimb placing test } \\
\text { Cylinder test }\end{array}$ & [32] \\
\hline & hiPSC-NSC & Cortex surrounding lesion & Pig, MCAo & MRI and histology (no functional measurement) & [33] \\
\hline \multirow[t]{2}{*}{ Epilepsy } & hESC-MGE progenitors & Hippocampus & Mouse, Pilocarpine-induced TLE & $\begin{array}{c}\text { EEG recording } \\
\text { Novel object recognition test } \\
\text { Locomotion test } \\
\text { Handling test }\end{array}$ & [34] \\
\hline & hESC-MGE progenitors & Hippocampus & Mouse, Pilocarpine-induced TLE & $\begin{array}{l}\text { Morris Water Maze test, } \\
\text { EEG recording }\end{array}$ & [35] \\
\hline \multirow{3}{*}{$\begin{array}{l}\text { Learning and } \\
\text { Memory/AD }\end{array}$} & $\begin{array}{l}\text { hiPSC-NPCs (with cholinergic } \\
\text { neuronal phenotype) }\end{array}$ & Bilateral hippocampus & Mouse, Tg PDAPP & Morris Water Maze test & [36] \\
\hline & hESC-BFCN Progenitors & Bilateral Hippocampus & Mouse, $\operatorname{Tg} 5 \mathrm{XFAD}$ and & $\begin{array}{c}\text { Morris Water Maze test } \\
\text { Electrophysiology (Whole-Cell patch-clamp) }\end{array}$ & [37] \\
\hline & hiPSC-ML/NEP2 & Hippocampus & Mouse, $\operatorname{Tg} 5$ XFAD & $\begin{array}{l}\text { Immuno-histochemistry } \\
\text { (no functional assay) }\end{array}$ & [38] \\
\hline
\end{tabular}


Table 1. Cont.

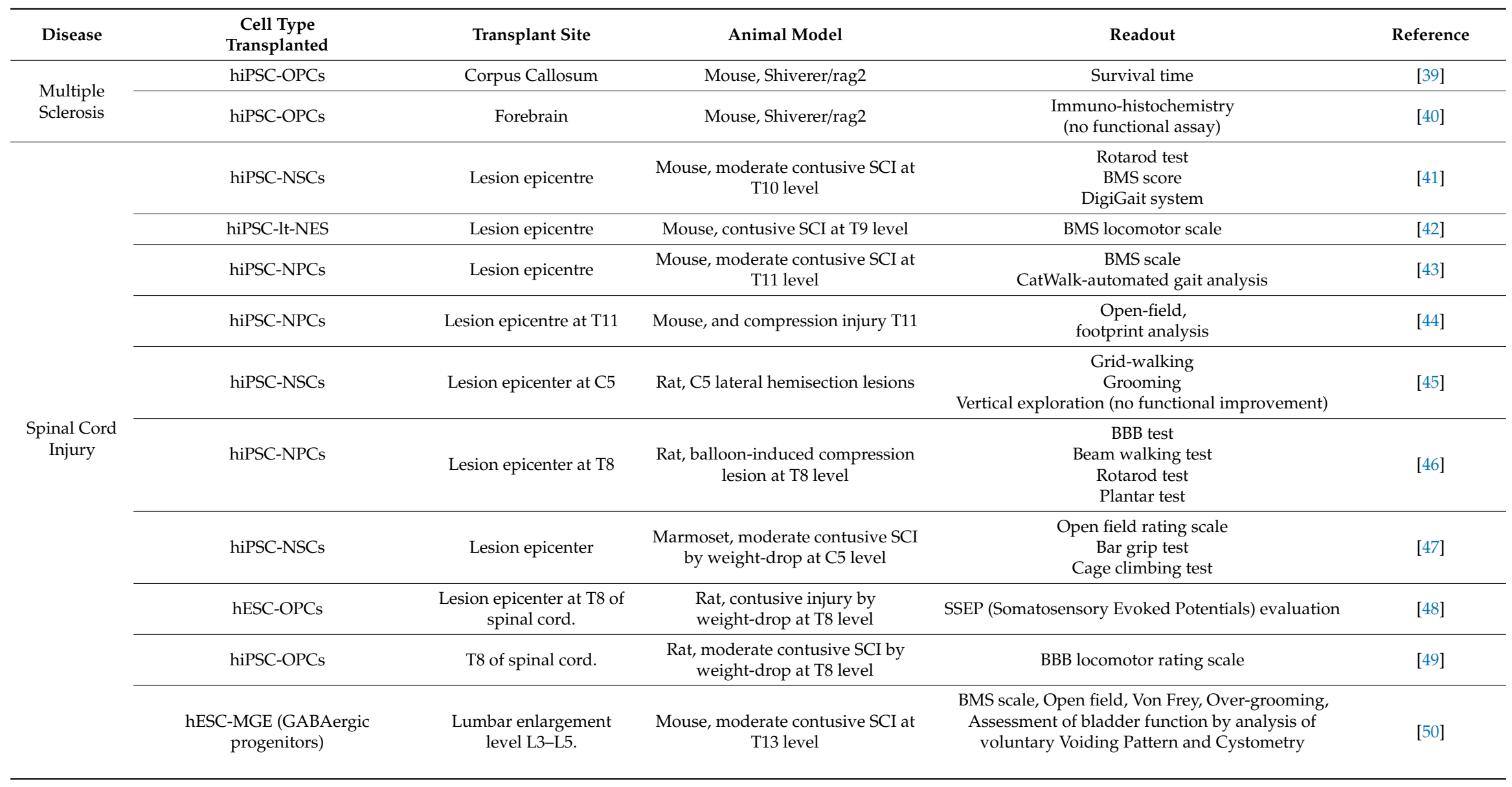


Table 1. Cont

\begin{tabular}{|c|c|c|c|c|c|}
\hline Disease & $\begin{array}{c}\text { Cell Type } \\
\text { Transplanted }\end{array}$ & Transplant Site & Animal Model & Readout & Reference \\
\hline \multirow[b]{2}{*}{$\begin{array}{l}\text { Neuropathic } \\
\text { Pain }\end{array}$} & hESC-MGE progenitors & $\begin{array}{l}\text { Spinal Cord, Lumbar } \\
\text { enlargement (L3-L5) }\end{array}$ & $\begin{array}{l}\text { Mouse, moderate contusive SCI at } \\
\text { T13 level }\end{array}$ & BMS scale, Open Field, Von Frey, Over-grooming. & [50] \\
\hline & hiPSC-GABAergic neurons & $\begin{array}{l}\text { Spinal Cord, Lumbar } \\
\text { enlargement L1. }\end{array}$ & Mouse, SNI & $\begin{array}{l}\text { BMS scale } \\
\text { Von Frey, } \\
\text { Acetone } \\
\text { Open Field, }\end{array}$ & [51] \\
\hline
\end{tabular}

PD: Parkinson's Disease; AD: Alzheimer's Disease. SCI: Spinal Cord injury; hESC: human Embryonic Stem Cells; NSC: Neural Stem Cells; NPC: Neuronal Progenitor Cells; hiPSC: human

Pluripotent Stem Cells; DANs: Dopaminergic neurons; lt-NES: long-term self-renewing Neuro-Epithelial-like Stem; ML/NEP2: Macrophage-Like/Neprilysin-2; BFCN: Basic Forebrain

Cholinergic Neurons; OPC: Oligodendrocyte Progenitor Cells; MGE: Medial Ganglionic Eminence; SNI: Spared Nerve Injury. 
A pioneering study used a co-culture system of telomerase-immortalized human fetal midbrain astrocytes with hESC to achieve high-efficiency dopaminergic neurogenesis in hESC. This highly enriched DANs population provided significant functional benefit when transplanted into the striatum of the 6-hydroxydopamine (6-OHDA)-lesioned rat model of PD [13]. While this study represented an important steppingstone in the development of a stem cell-based therapy for PD, it also raised the concern of tumor formation due to the presence of proliferating undifferentiated neuro-epithelial cells in the graft.

Prolonged maturation of hESC-DANs in vitro prior to transplantation was showed to reduce the risk of tumor formation without affecting their function and efficacy in a primate model of PD [14]. More efficient and defined protocols, based on dual SMAD inhibition and activation of the Wnt signaling, have also been developed. Midbrain DANs expressing tyrosine hydroxylase $(\mathrm{TH}$, the rate limiting enzyme in the synthesis of DA) were derived from hESC. Their function and efficacy in vivo was demonstrated in PD models using three host species. HESC-midbrain DANs engrafted in 6-OHDA-lesioned mice and rats and their survival was associated with an amelioration of amphetamine induced rotation behavior and bradykinesia. Scalability of the procedure was confirmed in parkinsonian monkeys and safety was suggested by the lack of tumor formation in the three animal models [15]. A similar approach is based on dual SMAD inhibition, modulation of the Wnt signaling pathway and embryoid body (EB) formation to direct hESC differentiation toward a ventral mesencephalic (VM) fate and generate an enriched population of floor-plate progenitors. When transplanted into the brain of a rat model of PD, hESC-derived VM progenitors differentiated into functional midbrain DANs, released DA in vivo 18 weeks post-transplantation and reversed motor impairments (amphetamine-induced rotational asymmetry) in 6-OHDA-lesioned rats [16] with an efficacy comparable to that seen with human fetal VM cells [17]. HESC-DANs are capable of long-distance innervation of the host brain [17]. However, the overall proportion of hESC-derived DANs within the grafted region remains low, due in part to their poor survival immediately following transplantation. Glial cell line-derived neurotrophic factor (GDNF) has recently been shown to increase the survival, plasticity, and functional integration of hPSC-derived VM DA progenitor grafts, in a time post-transplantation-dependent manner [18]. Interestingly, a new cell type resembling perivascular-like cells, called vascular leptomeningeal cells (VLMC), has very recently been identified in hESC-DANergic grafts [52]. The contribution of this population to the graft survival and function remains to be determined.

Autologous human induced pluripotent stem cells (hiPSCs) cells potentially represent a more tolerable cell transplantation option than hESC and have attracted significant interest [19-21,23]. Han et al., 2015 confirmed that hiPSC-derived NSCs integrated into the host brain circuitry and differentiated to DA neurons when transplanted into the striatum of 6-OHDA PD rats. Functional recovery was evident from the 4 th to the 16th week after transplantation. However, a greater proportion of NSCs differentiated to astrocytes than neurons, with efficiencies of $51.1 \%$ and $20.5 \%$ respectively [22]. Other studies avoided this issue by directly transplanting hiPSC-derived DANs into the striatum of 6-OHDA rats, observing functional recovery using the amphetamine-induced rotation test and highlighting no difference in results when comparing DANs derived from healthy or PD hiPSC lines $[19,20]$. PD-hiPSC-DANs do not show increased vulnerability to external toxic stresses compared to those generated from healthy individuals. Furthermore, when transplanted in the brain of $\alpha$-synuclein overexpressing transgenic mouse model of PD [53], PD hiPSC-derived DANs did not exacerbate pathological $\alpha$-synuclein accumulation in the host brain or in the grafts, suggesting that hiPSC derived from PD patients are suitable for autologous cell transplantation [20]. A reduction in motor deficits was also observed after transplantation of NPCs or DANs from hiPSC into the right side of the rat striatum [21]. However, three of twelve grafted rats showed tumor growth and subsequent death before eight weeks suggesting the presence of oncogenic factors or remaining undifferentiated cells. Despite the differences in the nature of the cell transplanted, these studies in rodents demonstrated functional recovery. Therefore, transplantation of hPSC-derived neuronal cells represents a potential therapeutic strategy to treat PD. 
In addition to rodent models, non-human primate (NHP) models of PD have been used to test hiPSC-based therapy. Following bilateral transplantation of hiPSC-derived NPCs into the putamen of MPTP (1-methyl-4-phenyl-1,2,3,6-tetrahydropyridine)-treated cynomolgus monkey, cells survived for six months and differentiated into DANs. A single parkinsonian monkey was transplanted and behaviorally assessed for skilled reaching. Results showed a slight functional improvement [23]. A subsequent analysis from the same group found improved neurological rating scores and higher recovery rates after transplantation of hiPSC-derived DA progenitors into the putamen of MPTP-treated cynomolgus monkeys. HiPSC-DA progenitor cells matured and survived for at least 12 months after transplantation and the efficacy of the cell therapy was similar to that of L-DOPA treatment. Moreover, the effects were similar whether the donor cells were from healthy individuals or PD patients [24]. Following this study in NHPs, which was a simulation of a planned clinical trial and confirmed the efficacy and safety of hiPSC-derived DA progenitors, a Phase I clinical trial in human PD patients was initiated in 2018 in Japan, and others are planned for the near future in the US and in Europe [7,54,55]. Current clinical trials using hPSC-derived neuronal cells for neurodegenerative diseases/injuries are summarized in Table 2.

Table 2. Clinical trials using hPSC derivatives for diseases/injuries of the nervous system.

\begin{tabular}{ccccc}
\hline Disease & Treatment Type & Phase & $\begin{array}{c}\text { Clinical Trial } \\
\text { Identifier }\end{array}$ & Country \\
\hline PD & $\begin{array}{c}\text { parthenogenetic } \\
\text { hESC-NSC } \\
\text { (ISC-hpNSC) }\end{array}$ & Phase I & NCT02452723 & Australia \\
\cline { 2 - 5 } & $\begin{array}{c}\text { HLA-matched } \\
\text { hESC-NPC }\end{array}$ & Phase I/II & NCT03119636 & China \\
\cline { 2 - 5 } & $\begin{array}{c}\text { hiPSC-DA } \\
\text { Progenitors }\end{array}$ & Phase I/II & $\begin{array}{c}\text { JMA-IIA00384 } \\
\text { UMIN000033564 }\end{array}$ & Japan \\
\hline $\begin{array}{c}\text { Amyotrophic Lateral } \\
\text { Sclerosis (ALS) }\end{array}$ & $\begin{array}{c}\text { hES-Astrocystes } \\
\text { (AstroRx) }\end{array}$ & Phase I/II & NCT03482050 & Israel \\
\hline SCI & $\begin{array}{c}\text { hESC-OPC } \\
\text { (AST-OPC1) }\end{array}$ & Phase I/II & NCT02302157 & USA \\
\hline
\end{tabular}

PD: Parkinson's Disease; SCI: Spinal Cord injury; hESC: human Embryonic Stem Cells; HLA: Human Leucocyte Antigen; NSC: Neural Stem Cells; NPC: Neuronal Progenitor Cells; hiPSC: human Pluripotent Stem Cells; DA: Dopamine; OPC: Oligodendrocyte Progenitor Cells.

Together, these studies build on evidence that an hPSC-based therapy has considerable potential for reversing motor defects of PD patients. The replacement of DANs from the substantia nigra by hPSC-DANs restores the deficit of dopamine release, subsequently stimulating the medium spiny neurons of the striatum and alleviating PD disabilities that include bradykinesia, resting tremor and muscle rigidity. Cell replacement therapy also could reduce the side effects of medication such as dyskinesia (uncontrolled involuntary movements) resulting from the long-term use of Levodopa. A major limitation of such treatment however is its sole focus on motor symptoms, which comprise only part of PD pathology. It remains unclear whether any of these treatments will have an impact on the non-motor symptoms of PD including mood disorders, such as depression, and cognitive decline.

\subsection{Stroke}

Despite stroke being a significant cause of disability in adults [56], outside of long-term rehabilitation, few therapeutic strategies exist to treat the condition. Stroke is characterized by a sudden interruption of blood flow in a particular area of the brain. It can lead to death of a range of neuronal cell types with limited regeneration potential and therefore, the use of hPSCs as a cell-based replacement therapy is a promising potential approach to promote recovery. Transplantation of neuronal cells derived from hPSCs can lead to functional improvement in animal models of 
stroke through several mechanisms including neuronal replacement, modulation of inflammation, neuroprotection and stimulation of angiogenesis [57] (Figure 2).

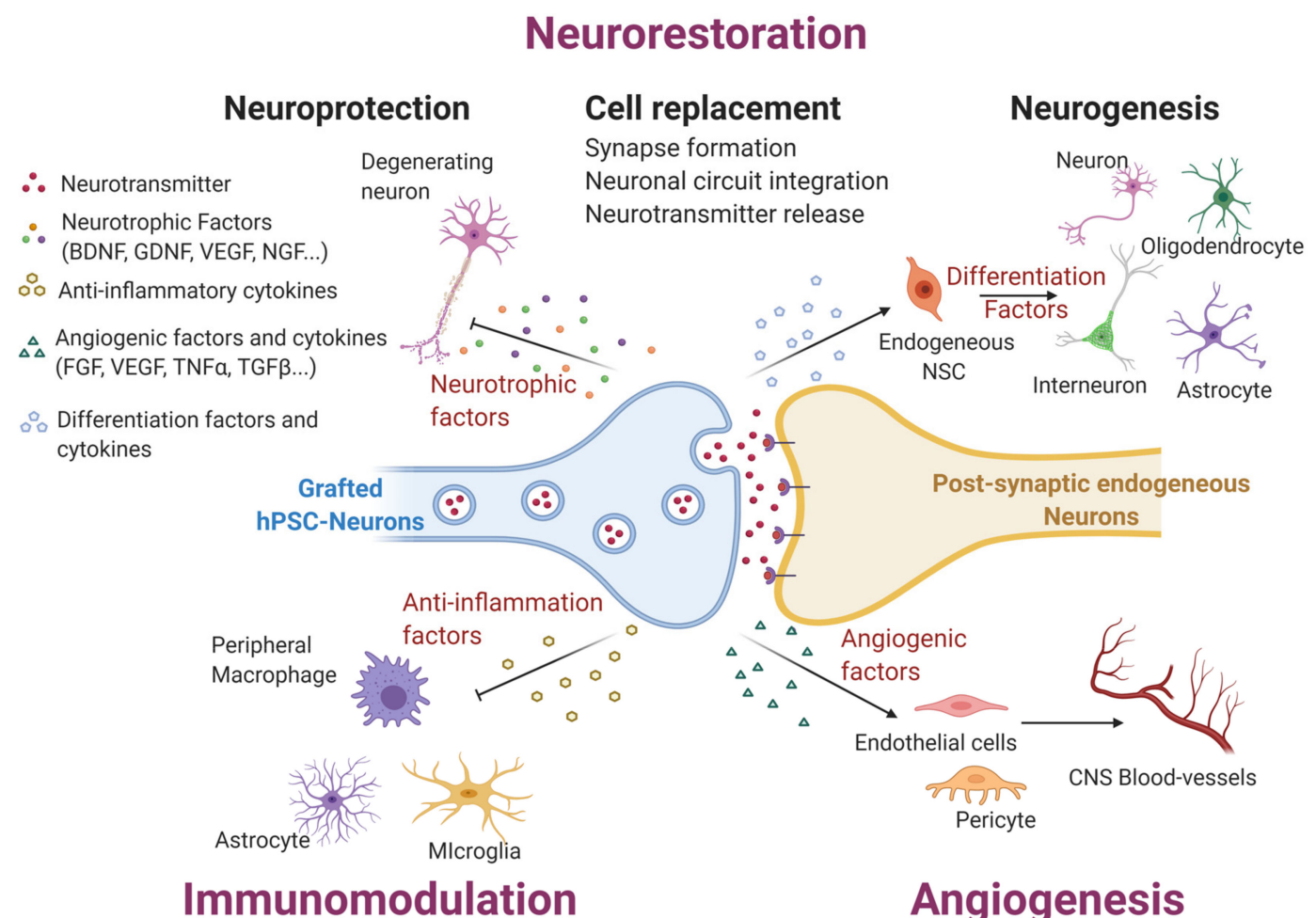

Figure 2. Potential mechanisms of hPSC-based therapies for neural tissue regeneration.

Due to the heterogeneity of cells lost in stroke, several different cell types have been used for transplantation therapies (Table 1, Figure 1). It remains unclear which of these cell types is most advantageous.

Long-term self-renewing neuro-epithelial-like stem (lt-NES) cells are multipotent progenitors that can give rise to glia and neurons and are most similar to the early neuroepithelium of the developing embryo. Lt-NES cells can be derived from human iPSC or ESC [58]. In contrast to differentiated cells that are already specialized, lt-NES cells are less lineage-restricted and can be instructed by local factors in vivo to further differentiate into the required neuronal lineages. This could have a major advantage in stroke where several neuronal cell types are damaged and directed differentiation to replace only one type of neurons might not provide maximum benefit. Previously, hiPSC-derived It-NES have shown some therapeutic promise following transplantation into the striatum or cortex of mice and rats that with stroke-damage from middle cerebral artery occlusion (MCAo) [25-27]. Recovery of movement was observed as shortly as one week after transplantation, suggesting that this rescue may be due to neurotrophic factors release, such as vascular endothelial growth factor (VEGF), rather than neuronal cell replacement. Transplanted lt-NES cells differentiate into several neuronal subtypes including cortical neurons, and demonstrate functional characteristics of neurons, such as action potential generation with integration into the host circuitry evident five months post-transplantation. Motor deficits were consequently attenuated [25]. HiPSC- 1t-NES which had been fated towards a cortical phenotype in vitro prior to transplantation showed less proliferation and more efficient conversion to mature neurons than non-fated cells [27]. Six months post-injection, transplanted hiPSC-fated cortical neurons receive direct and functional synaptic inputs from the stroke-injured brain [26], their axons are myelinated in the host brain and their terminals form excitatory glutamatergic synapses with host cortical neurons [28]. Furthermore, physiological sensory stimuli can modulate 
their spontaneous activity [26] and their activity can maintain normal motor function in MCAo rats [28], demonstrating functional integration of the grafted hiPSC-cortical neurons to the stroke-injured brains' neural circuitry. Whilst these studies show that lt-NES cells generally become committed and lose proliferative capacity in vivo, some cells remain proliferative and potentially tumorigenic. As such, the risk of graft overgrowth is a substantial concern.

As an alternative strategy, hiPSC-derived NPCs have been transplanted into stroke-damaged rodents and shown to be equally as effective in promoting functional recovery. Neuro-progenitor cells differ from IT-NES by their more limited capacity to proliferate, although they retain multipotency. This characteristic may help to mitigate the problem of graft overgrowth observed with It-NES and a number of studies have claimed significant success with this strategy in both mice and rats. NPCs (of telencephalic fate) transplanted into the striatum of ischemic mice survive, migrate and are associated with an improvement of modified neurological severity score (mNSS) for up to six weeks post-transplantation. The functional recovery observed in the transplanted group could be explained by neural circuit reconstitution [29]. Similar results were found using the adhesive removal test where the latency/speed of removal is measured. HiPSC-NPCs transplantation not only enhanced sensorimotor functional recovery but also reportedly increased trophic support and improved blood flow in the cortex by restoring neurovascular coupling up to 28 days post-transplantation. However, the study did not assess the relative contributions of different neural cell types to recovery [30]. Similarly, hiPSC-NPCs transplantation into the brain of stroke damaged rats also leads to functional improvement in both rotarod and stepping tests, with initial motor recovery from one-week post-transplantation. A more gradual recovery was however observed in two other metrics, the apomorphine-induced rotation tests and the mNSS. The study highlighted the short-term effects of hiPSC-NPCs and demonstrated their different mode of actions by showing the formation of neuronal tissues from the transplanted hiPSC-NPCs and the reduction of inflammation, gliosis and apoptosis in the damaged brain [31]. More recently, improvement in limb asymmetry was achieved by transplantation of hiPSC-NPCs into the right cortex of MCAO stroke-damaged rats. However, there were only modest improvements in motor function, suggesting further clinical development would be required [32].

To date, only one study involving the use of hiPSC has been carried out in a non-rodent stroke model. HiPSC-NSCs were transplanted into the brain parenchyma surrounding MRI-identified lesions of an ischemic pig stroke model and were shown to survive long-term, differentiate to neurons and oligodendrocytes and improve tissue recovery in the damaged brain. Metabolic effects were recorded post-transplantation, such as reduced changes in white matter integrity, enhanced cerebral blood perfusion and recovery of brain metabolism in the damaged tissue. HiPSC-NSC post-stroke transplantation also lead to neuronal protection and reduced microglial activation. However, no confirmation of functional recovery was assessed in this study [33].

A limitation of the field is that only short-term studies have been carried out to date. Longer-term functional follow-ups are necessary to provide evidence of therapeutic efficacy. Stroke is also a difficult disease to model as the pathology depends on the brain regions affected. From these studies it remains unclear whether functional recovery could be attained in all brain regions and the extent to which the degree of neuropathology alters the results.

\subsection{Epilepsy}

Epilepsy is a common neurological disorder which manifests by an excessive, rhythmic (ictal) and abnormal brain activity causing spontaneous recurrent seizures, unusual behavior or sensations and loss of consciousness. Dysfunction of GABAergic inhibitory interneurons plays a major role in the pathological hyper-excitability underlying epilepsy, owing to their responsibility for dampening neuronal activity and promoting network inhibition. Inflammation also has a significant role in epilepsy. However, there is an active debate as to whether inflammation is the cause or consequence of epilepsy [59,60]. Although many anticonvulsants drugs are used in the treatment of epilepsy, their efficacy varies greatly between individuals and adverse effects are near ubiquitous 
amongst patients [61]. Moreover, many patients cannot be successfully stabilized on anticonvulsants, necessitating drastic surgery such as surgical resection of the epileptic focus (the center of epileptic rictal activity). Consequently, the development of a stem cell-based therapy could represent a great advantage for the treatment of epilepsy.

HESC s can be differentiated into medial ganglionic eminence (MGE) cells, precursors of GABAergic interneurons (GINs). Significant cognitive improvement was observed after transplantation of hESC-MGE progenitors into the hippocampus of a pilocarpine-induced temporal lobe epilepsy (TLE) mouse model. Grafted hESC-MGE progenitor cells differentiated into active GABAergic neurons with mature firing patterns, showing their integration into the host hippocampal circuitry and suggesting a synaptic mode of action $[34,35]$. Alternatively, hESC-interneuron grafts can ameliorate memory impairment through release of GABA or neurotrophic factors that protect hippocampal neurons and synaptic integrity, or by releasing factors that reduce inflammation which is known to impair learning and memory $[62,63]$.

In one of the studies, transplanted cells were also functionally effective at reducing seizure activity for up to four months post-transplantation, which was directly attributed to transplant-derived inhibitory currents passed onto endogenous hippocampal neurons [34]. However, the more recent study did not show significant seizure suppression after transplantation of hESC-GABA neurons progenitors into the brain of TLE mice compared to media injection [35]. Moreover, in this study, tumor-like NSC clusters were also observed in some injected mice, likely due to proliferative undifferentiated cells remaining in the transplanted population. The discrepancies between the two studies might therefore be explained by the difference in heterogeneity of the transplanted cell populations. Although hPSC-based therapies have great potential in the treatment of epilepsy, further studies are necessary in both rodent and non-rodent models to prove their efficacy in suppressing seizures and importantly to ascertain the safety of the procedure.

\subsection{Learning \& Memory Disorders/Dementia (Alzheimer's Disease)}

Learning and memory are complex cognitive processes involving hippocampal function that are severely affected by aging and some neurodegenerative disorders such as Alzheimer's disease (AD). AD is the most common age-related form of dementia and is clinically characterized by a progressive loss of cholinergic neurons and synapses, deposition of neurotoxic proteins such as extracellular amyloid- $\beta$ (A $\beta$ ) plaques and intracellular neurofibrillary tangles (NFTs) [64]. While AD is currently untreatable, increasing evidence supports the therapeutic potential of regenerative medicine to treat AD.

Over the last decade, numerous preclinical stem cell therapies have been attempted to replace lost neurons or support existing neurons in animal models of AD. NSCs derived from mouse adult brain or ESC were transplanted into AD rodent models and resulted in generation of cholinergic neurons, increased synaptic strength and enhancement of memory performance [65-67]. Improvements in learning and memory abilities have also been demonstrated after hPSC-based cell replacement therapies (Table 1, Figure 1). HiPSC-NPCs of cholinergic phenotype were transplanted into the hippocampus of the PDAPP (PDGF promoter driven amyloid precursor protein) transgenic mouse model of dementia [68]. By 45 days post-transplantation, hiPSC-NPCs were found to survive and differentiate into cholinergic and GABAergic neurons in the host brain, resulting in an improvement in spatial memory [36]. Mouse and human ESC were also directed to differentiate into basic forebrain cholinergic neurons $(\mathrm{BFCN})$ progenitors and transplanted into the forebrain of AD mouse models. Two months after the injection, transplanted BFCN progenitors predominantly differentiated into mature cholinergic neurons that functionally integrated into the host endogenous cholinergic circuitry. HESC-BFCN therapy could restore cholinergic function and alleviate cognitive deficits of two strains of AD mouse models (5XFAD and APP/PS1) up to six months post-transplantation [37]. These results demonstrate great potential for hPSC transplantation to improve learning and memory disorders such as AD. 
Accumulating evidence suggests that stem cells transplantation influences the pathological features of AD through multiple modes of action. Similar to stroke, the therapeutic potential can be partly attributed to a paracrine effect of neurotrophic factors (in this case BDNF and GDNF) that ameliorate various cellular functions in animal models of $\mathrm{AD}$, including neural integrity, endogenous neurogenesis, microglial activity, angiogenesis, mitochondrial function, autophagy and apoptosis $[69,70]$ together improving cognitive function. Of interest, while Huntington's disease (HD) is commonly referred as a motor disorder, cognitive impairments are present and often progress to dementia. Similar behavioral improvements have been found after transplantation of mouse and human iPSC-NPCs into the striatum of $Y A C 128$ HD mice [71,72]. Transplanted cells were shown to differentiate into medium spiny neurons [71], the most affected neuronal cell type in HD, as well as GABAergic neurons [72]. HPSC-NPC may also represent an effective neuronal cell replacement therapy for HD.

While most NPC/NSC and BFCN transplantations were successful at improving cognitive dysfunction in $\mathrm{AD}$ animal models, they failed to reduce the level of $\mathrm{A} \beta$ plaques in the $\mathrm{AD}$ brain. Following a different strategy, hiPSC-derived macrophage-like (ML) cells were generated and engineered to express Neprilysin-2 (NEP2), a secretable protease with A $\beta$-degrading activity. HiPSC-ML/NEP2 were injected into the hippocampus of the 5XFAD transgenic AD mice [38,73]. Although the effect on cognitive function and neuronal damage was not examined, a significant reduction in the level of $A \beta$ was observed in the transplanted mouse brain. The reduction of $A \beta$ was not significant when unmodified hiPSC-ML were transplanted, demonstrating that the secretion of NEP2, and not phagocytosis by hiPSC-ML, caused the elimination of A $\beta$. While further investigations are necessary to evaluate their protective effect on neuronal damage and subsequent cognitive decline, this study suggests a potential therapeutic benefit of NEP2-secreting hiPSC-ML for the treatment of $\mathrm{AD}$.

\subsection{Multiple Sclerosis}

Multiple Sclerosis (MS) is a chronic demyelinating disease that affects the CNS. Current therapies are primarily directed against the immune system to treat the inflammatory component of the disorder. However, the real challenge is to develop re-myelinating and neuro-protective therapies.

To establish a potential source of myelinogenic oligodendrocytes for the treatment of MS, several protocols were developed to generate oligodendrocyte precursors cells (OPCs) from hiPSC $[39,74,75]$. HiPSC-OPCs were transplanted into the corpus callosum of a genetic model of congenital hypomyelination, the shiverer mouse [76]. In vivo, hiPSC-OPCs differentiated into oligodendrocytes that produced myelin and had the ability to efficiently myelinate the hypomyelinated shiverer brain with no evidence of tumorigenesis at nine months post-transplantation. Furthermore, the transplants led to a significant functional improvement and significantly increased lifespan by $\sim 20 \%$ compared to their untreated counterparts [39]. Importantly, when hiPSC were derived from four progressive MS patients they could also be induced to form highly enriched populations of OPCs. Although no functional assay was performed in this study, immunohistochemistry demonstrated that the transplanted hiPSC-OPCs differentiated, expressed mature oligodendrocyte markers after transplantation in vivo and myelinated axons in an immuno-compromised shiverer mouse brain, highlighting the potential of autologous hiPSCs to treat MS [40].

\subsection{Spinal Cord Injury}

Spinal cord injury (SCI) often results in catastrophic neurological deficits which dramatically diminish the quality of life of affected individuals. Surgery (laminotomy which involves the surgical removal of bone to relieve pressure in the spinal canal) and rehabilitation are the only interventions commonly used to improve functional recovery after SCI. The corticosteroid methylprednisolone is the only pharmacotherapy currently approved and has been used to reduce inflammation in the spinal cord (SC) acutely after injury. However, it has limited efficacy and serious side-effects, such as gastrointestinal hemorrhage and respiratory bacterial infection, and this medication is no longer 
routinely provided [77]. Despite decades of efforts to develop effective treatments, there is still an urgent need for new therapeutics that promote functional recovery after SCI.

Central to the pathology of SCI is a major insult to the nervous system. A trauma of the spinal cord can cause acute damage to ascending and descending tracts and lead to axotomy (severing of axons). Immediately after primary injury, a robust neuro-inflammatory response occurs and triggers the secondary injury mechanisms in the chronic phases of SCI, leading to cell death and further tissue degeneration (Wallerian degeneration). Around the site of the injury, the formation of a cyst and a growth inhibitory scar (known as the glial scar) will prevent tissue regeneration [78]. For these reasons, stem cells, in particular hiPSC, have attracted great interest as a potential source for cell replacement therapy after SCI.

Human iPSC-derived neurospheres were transplanted into a mouse model of contusive SCI at the T10 level [41]. The cells differentiated to neurons, oligodendrocytes and astrocytes. Functional recovery was evident 112 days after injury in multiple motor parameters including gait and overall locomotion. However, only $22 \%$ of the cells differentiated into mature neurons. In a further study using hiPSC-lt-NES transplanted in a mouse at the T9 level, 75\% of transplanted cells differentiated to neurons. Functional recovery of the hindlimb was found using the Basso Mouse Scale (BMS) and was associated with improvements in the motor evoked potential (recorded from the hindlimb and stimulated in motor cortex) [42].

HiPSC-NPCs have also been transplanted into an immuno-competent mouse model of SCI but showed very limited survival, no reduction of the size of the lesion and no functional recovery [43]. In contrast, functional improvement of hindlimb dysfunction and structural recovery of the spinal cord were evident following transplantation of hiPSC-NPC in a mouse study [44]. The same discrepancies were reported in rat models of SCI. HiPS-NPCs were injected into C5 lesion sites of immunodeficient rats. Although the majority of cells differentiated to neurons whose axons were found to have integrated and formed synapses with host neurons three months post-transplantation, there was no functional improvement (assessed by the grid-walking, grooming, and vertical exploration) [45]. In contrast, a study with a much larger sample size (34 transplanted and 35 control rats) showed clear functional motor improvement (measured by the Basso, Beattie and Bresnahan (BBB) locomotor scale method, beam walking, rotarod and plantar test) after transplantation of hiPSC-NPCs at the T8 level of the spinal cord. After 17 weeks, hiPSC-NPCs differentiated to astrocytes, oligodendrocytes and specific neurons (interneurons, dopaminergic, serotoninergic and motor neurons), but a large portion of the grafts was glial cells. Interestingly, human ChAT (cholineacetyltrabsferase) positive motor neurons were found in the ventral part of the spinal cord while human calbindin expressing interneurons were localized in the central part of the SC, showing that the cells can migrate to specific regions of the tissue and adopt specific phenotypes [46]. Despite promising results, the degree of functional recovery after stem cell transplantation remains modest. Recently, Notch activation induced by injury in the SC has been shown to orient transplanted hiPSC-NPCs towards astrocyte lineage and reduce their therapeutic efficiency [79]. Remarkably, modulation of notch signaling by GDNF in transplanted cells increased their neuronal fate and enhanced their electrical integration independently of an effect on cell survival. This strategy resulted in an improved functional recovery after transplant and represents an important optimization of hiPSC-NPCs therapy for SCI.

HiPSC-NSCs have also been trialed as cell therapy in a marmoset model of SCI. Injury was induced at the $\mathrm{C} 5$ level of the spinal cord and behavioral analyses were performed for up to 12 weeks afterwards. Functional recovery was observed in motor parameters such as open field, bar grip and cage climbing tests. However, although transplanted cells were found to differentiate into all three lineages (neurons, astrocytes and oligodendrocytes), approximately one quarter of the cells remained immature. Despite this limitation, no tumorigenicity was observed in the limited time frame of the study [47]. Longer and additional studies in large animals would be required to reinforce the current evidence.

Because re-myelination of axons is an essential component of the recovery, others have evaluated the therapeutic potential of OPCs, derived from hESC or hiPSC, for the restoration of neuronal pathways 
after moderate contusive SCI in rats. In both cases, most cells differentiated to mature oligodendrocytes expressing Myelin Basic Protein (MBP) and integrated in the host spinal cord. Transplanted $2 \mathrm{~h}$ after injury, hESC-OPCs lead to an improvement of somatosensory evoked potential (SSEPs) recorded at the cortex showing functional improvement of sensory pathways [48]. Transplantation of hiPSC-OPCs $24 \mathrm{~h}$ after injury resulted in a reduction of the cavity size and glial scarring at the injury site. A significant increase in number of myelinated axons was also reported. Although the mechanisms involved are still unclear, hiPSC-OPCs improve recovery of motor function (measured using the BBB scale) after transplantation into SCI [49]. Of note, mouse iPSC- NSCs derived from both wildtype and shiverer mice were transplanted into the spinal cord of a mouse model of SCI at the T6 level. While both cell lines integrated and differentiated into oligodendrocytes, astrocytes and neurons, wildtype-derived cells demonstrated a much greater improvement in locomotor function, demonstrating the key role of re-myelination in functional recovery of the spinal cord [80].

Lastly, some investigations have focused on other pathological aspects of SCI, which include neurogenic bladder disorders and neuropathic pain. A shared hallmark of both conditions is the loss of GABAergic inhibitory tone in the injured spinal cord [81,82]. HESC were induced to form MGE progenitor cells and transplanted in the lumbar enlargement of SCI mice. By six months post-transplantation, hESC-MGE progenitors integrated and differentiated into mature GABAergic neurons and glial cells. HESC-MGE grafts improved neurogenic bladder dysfunction and relieved central neuropathic pain, two of the most debilitating SCI-related symptoms [50].

Despite all preclinical studies performed in rodents to establish an hPSC-based approach for spinal regenerative medicine, clinical trials using hPSC to target SCI have not been fully conducted. The Food and Drug Administration (FDA) approved the first clinical trial in the US for the use of hESC-derived oligodendrocytes to treat SCI. Geron Corporation started the trial on 4 patients in 2010 but it was later closed for business reasons. Asterias Biotherapeutics re-initiated a Phase 1/2a Dose Escalation Study with 25 patients in 2015 but, to date, no results have been reported (Clinical Trial ID NCT02302157, Table 2). Clinical trials using transplantation of hiPSC-NPCs are also scheduled to start in Japan [8].

\subsection{Neuropathic Pain}

Chronic neuropathic pain is an exacerbated or prolonged pain caused by damage or disease affecting the somatosensory nervous system (including nerve injury, cancer, diabetes or viral infection). Chronic neuropathic pain can be classified as a neurodegenerative disease $[83,84]$ that culminates in decreased central inhibition in the spinal cord [85-87].

Neuropathic pain is currently treated with non-specific management strategies such as anti-epileptics, antidepressants and, in some cases, opioids. However, these treatments are known to have poor efficiency, produce undesirable side effects and/or long term addiction [88,89]. Cell replacement therapies to treat neuropathic pain have been explored as a means to increase GABA locally at the site of central dysfunction. Functional replacement of spinal GABAergic inhibitory neurons has been initially performed by the transplant of mouse embryonic MGE progenitor cells and resulted in attenuation of neuropathic pain by restoring central inhibition through release of GABA $[90,91]$. HESC-MGE progenitor cells have also been transplanted into the mouse spinal cord and shown to alleviate central neuropathic pain following SCI [50]. Most recently, we have generated matured functional GABAergic neurons from hiPSC and transplanted them into the spinal cord of mice with established peripheral nerve injury, providing pain relief for up to two months without damaging the spinal cord or affecting the mice motor function [51]. Given the potent analgesic effect of the GABAergic transplants and the resultant potential for its clinical use, a long-term study is currently underway to ascertain the efficacy and safety of this procedure. However, a limitation of this strategy is the control of GABAergic neurons migration and GABA release. An excessive restoration of central inhibition in the spinal cord, especially in the ventral horn, could potentially affect motor function and lead to debilitating disorders. 


\section{Current Challenges}

The challenges in the clinical application of hPSC transplantation for the treatment of neurodegenerative diseases or conditions fall broadly into two categories: issues with hPSC transplantation generally (including hPSC generation and differentiation), and those specific to the regeneration of the central nervous system (Figure 3).

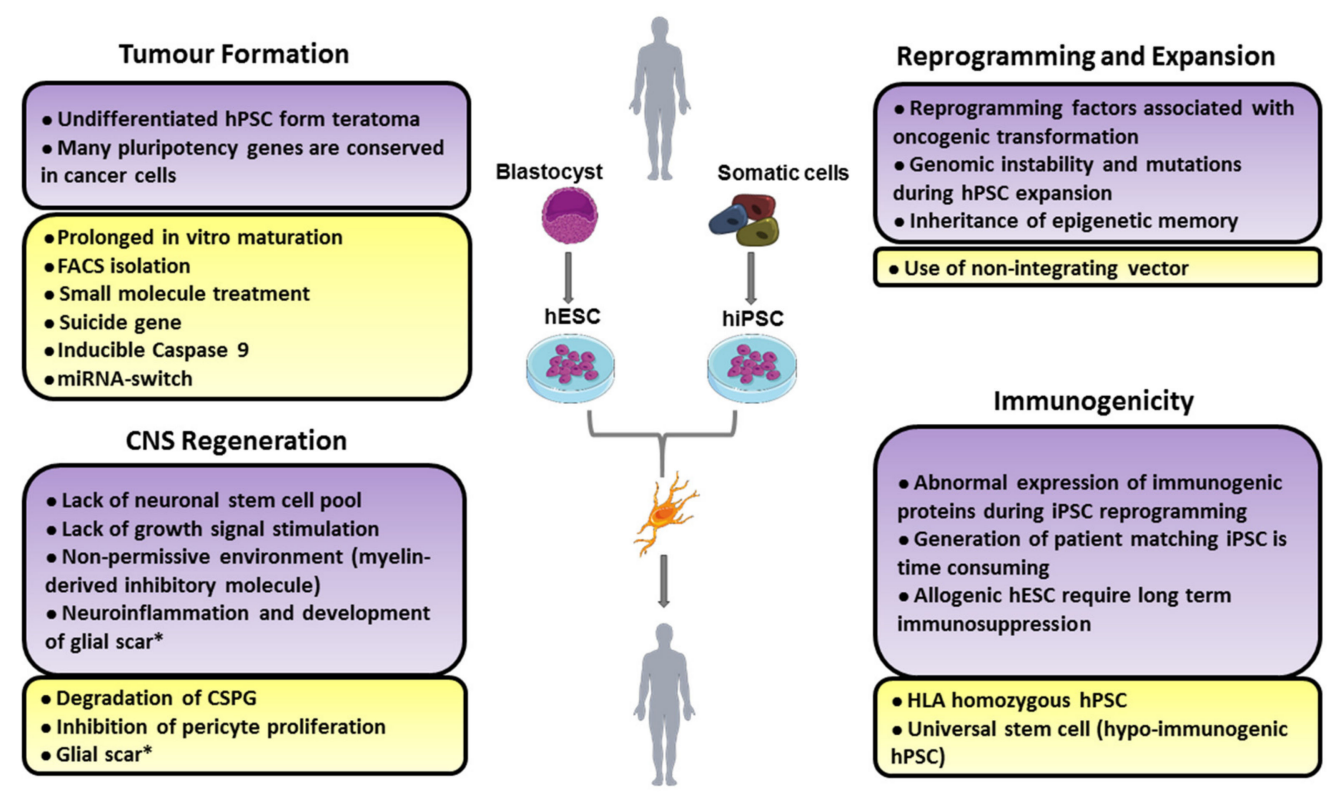

Figure 3. Challenges in clinical application of hPSC transplantation for the treatment of neurodegenerative diseases. In purple are summarized the current issues associated with the use of hPSC in regenerative medicine of the CNS, in yellow the potential solutions. * Note contradictory findings regarding the role of glial scar in CNS regeneration.

\subsection{Transplantation of Stem Cells}

\subsubsection{Pluripotency and Cancer}

Pluripotent stem cells have the unlimited capability to self-renew and differentiate into virtually all cell types of the body. These attributes make them an attractive candidate for cell replacement therapies and hPSC hold much hope for regenerative medicine. However, when transplanted in vivo undifferentiated hPSC form teratomas and the risk of tumor formation has largely restricted the clinical application of hPSC.

Pluripotent stem cells share a number of characteristics with cancer cells. Both fundamentally possess an indefinite capacity to proliferate, the ability to bypass DNA repair checkpoints $[92,93]$ and express oncogenic markers. For example, c-MYC transcription factor (TF) is highly expressed in both cancerous cells [94-96] and hESC [97,98] and is central for generating iPSC [99,100]. Recently, $c$-MYC has been identified as the major oncogenic effector of Wnt $/ \beta$-catenin signaling in $\mathrm{hESC}$ tumorigenicity [101]. Many of the genes and networks associated with pluripotency are also conserved in cancerous cells. The key pluripotency marker OCT4 is involved in the development of multiple cancers, such as ovarian [102,103], cervical [104], colorectal [105,106], liver [107], and oral cancer [108]. Generally, OCT4 expression correlates with worse cancer outcome in most tumors [109], while its down-regulation is associated with slowed tumor progression [110]. OCT4 is not the only important pluripotency factor. It forms a complex with other TFs such as SOX2 and NANOG to regulate the expression of different genes and maintain ESCs in an undifferentiated state. NANOG also plays a role in the self-renewal of CD24+ cancer stem cells in hepatocellular carcinomas [111] and has been found aberrantly expressed in a variety of human cancers, including head and neck squamous cell carcinomas (HNSCC) [112,113]. 
SOX2 has been shown to be expressed in at least 25 different types of cancer and to drive cancer cell survival [114]. Another stemness factor, KLF-4 (Krïppel-like factor 4), has been reported to promote DNA repair checkpoint uncoupling and cellular proliferation in breast cancer by p53 suppression [115]. KLF4 also acts as an oncogene in Glioblastoma by supporting glioblastoma stem cells survival and promoting their proliferation [116]. Pluripotent stem cells are also known to possess many of the hallmarks of cancer, including lack of contact inhibition in vitro [117], loss of $p 53[118,119]$ and $R b$ (retinoblastoma tumor suppressor protein) inactivation regulating their cell cycle [120]. Furthermore, long-term culture generates cytogenetic abnormalities and stem cells are highly susceptible to acquire mutations that are advantageous to regrowth. Given the high genomic instability of hPSC, oncogenic mutations are likely to accumulate over time during the production of large quantities of cells needed for cell therapy. Notably, $44 \%$ of genes up-regulated as a result of genomic instability in hESCs were functionally linked to genes commonly expressed in a range of cancers [121]. An important example is the spontaneous acquisition of p53 mutations by both hiPSCs and hESCs in prolonged culture, similar to the ones observed in human cancer [9]. This may result in a high proportion of potentially tumorigenic cells within the culture, making the cells unsuitable for transplantation in humans.

After hPSC differentiation, residual undifferentiated or partially differentiated cells may remain and induce tumor formation when implanted into animal models. In the case of neurodegenerative diseases, the risk is not only the development of teratomas from undifferentiated hiPSC/hESC but also undifferentiated neural tumors, whether primitive neuroectodermal tumors or gliomas, from partially differentiated neuronal cells. Persistent proliferation and tumorigenic masses were observed after transplantation of hPSC neuronal derivatives in rodent models of PD [13,21], epilepsy [35], and SCI [122], which highlights the importance of developing efficient, safe and clinically relevant protocols for complete elimination of undifferentiated cells.

\subsubsection{Methods to Prevent Tumor Formation}

In an effort to overcome this issue, several strategies have been explored for the development of safer stem cell therapies. Prolonged maturation of hPSC-DANs in vitro prior to implantation has been shown to reduce graft overgrowth and tumor formation in primate model of PD brain [14]. However, although this study showed behavioral improvements of monkeys transplanted with mature hESC-DANs, the elimination of undifferentiated hESC could not fully prevent the risk of tumor formation due to persistent proliferating immature neural cells. Others have implemented a purification step by fluorescence activated cell sorting (FACS) to select more mature neuronal cells for transplantation, eliminate undifferentiated cells and avoid tumor formation $[15,34,50,123]$. Undifferentiated cells can also be eliminated using small molecules. Treatment of a hESC-derived population with chemical inhibitors of Survivin signaling (quercetin or YM155) induced selective apoptotic cell death of undifferentiated hPSCs and was sufficient to prevent teratoma formation after hPSC transplantation [124]. Inhibition of $\beta$-catenin signaling with chemical inhibitor FH535 in hESC reduced teratoma formation by $79 \%$. Although the $\beta$-catenin pathway plays a fundamental role in hESC self-renewal and maintenance of stem cell properties, its inhibition in hESC before induction of differentiation did not compromise their pluripotency [101]. Similarly, pre-treatment of hPSC-NPCs with $\gamma$-secretase inhibitor, an inhibitor of Notch signaling, decreased the proliferative capacities and promoted differentiation of undifferentiated neural cells, thereby preventing tumor formation upon transplantation into SCI model rodents [125].

Suicide genes have also been employed for the elimination of undifferentiated and potentially tumorigenic cells. Herpes simplex virus thymidine kinase (HSV-TK) is the most commonly used suicide gene in hESC/hiPSC and has proven efficient in eliminating tumor formation after transplantation [126-130]. However, of HSV-TK substrate ganciclovir has a poor capacity to cross the blood-brain barrier (BBB) [131] and its long-term administration is associated with potential health risks associated with, such as impairment of renal function, hepatic dysfunction, and pancytopenia [128]. The use of HSV-TK may therefore not be suitable in cell therapy, especially for neuronal disorders. 
Moreover, by targeting DNA synthesis, HSV-TK has the ability to induce apoptosis specifically in highly proliferative cells but may not be efficient to eliminate slowly dividing cells. A cell-cycle-independent fail-safe strategy using an inducible caspase 9 (iC9) gene has also shown its efficacy in ablating teratomas derived from iPSCs [132-134] or tumors originating from malignant transformation of transplanted hiPSC-NPCs in a mouse model of SCI [135]. A specific chemical inducer of dimerization (CID, AP1903) activates iC9 which subsequently triggers an apoptotic response that kills hPSCs or their derivatives within $24 \mathrm{~h}$. A less conventional method of "microRNA switch" (miR-switch) has also demonstrated success. MicroRNA-302-5p (miR-302a) is highly expressed in undifferentiated hPSC s but progressively decreases upon differentiation to become undetectable in fully differentiated cells. A miR-switch based on miR-302a activity was developed to identify residual undifferentiated and partially differentiated cells following differentiation of hiPSCs. Selective hiPSC elimination was achieved by controlling puromycin resistance using the miR-302a switch and prevented teratoma formation in an in vivo tumorigenicity assay [136].

All these approaches provide a safeguard for clinical use of hPSC-cell therapies. However, because most of hPSC transplantation studies are performed in immune-deficient animals or in presence of immune-suppressive drugs, the real risk of tumor formation in immune-competent hosts is mostly unknown. Recently, using multiple models of humanized mice it has been suggested that autologous hPSC-derived therapies are unlikely to form teratomas in the presence of natural killer (NK) cells [137].

\subsubsection{Oncogenic Risks Associated with Reprogramming}

Despite their obvious advantage, using hiPSC in regenerative medicine implies additional risks. Genome-wide studies have unveiled numbers of large and point mutations in hiPSC, leading to serious doubts regarding their safety and potential clinical applications $[138,139]$. It is therefore critical to evaluate the safety of hiPSC (and their derivatives) generated prior to transplantation. Following this idea, oncogenic mutations were detected in the hiPSCs reprogrammed from the somatic cells of the second patient enrolled in the clinical trial testing hiPSC-derived RPE as cell replacement therapy for macular degeneration. As a result, the transplantation of the second patient was postponed and the trial terminated. The mutations were not detectable in the patient's original fibroblasts [4].

Reprogramming adult somatic cells to a state of pluripotency requires their exposure to multiple reprograming factors (Oct4, Sox2, Klf4, c-Myc or Nanog and Lin-28) which are critical for both the acquisition and maintenance of induced pluripotency but can promote oncogenic transformation as previously discussed. The process of reprogramming itself also induces genomic alterations. Single nucleotide variations (SNVs) sometimes occur in the coding region of a gene, resulting in the expression of a mutated protein that can lose or gain function and become potentially harmful. Copy-number variations (CNVs), involving the duplication or deletion of a large portion of DNA, can also be generated by reprogramming, causing potentially dangerous mutations in different genes [140]. Furthermore, the first generations of iPSCs were reprogrammed using retrovirus as delivery method for reprogramming factors $[100,141]$ which integrate into the genome of the cells and therefore can cause potentially dangerous mutations. Non-integrative reprogramming methods that reduce the occurrence of genetic variations [142-144] have since been developed and are a prerequisite for clinical use of hPSC. These include DNA-based methods such as Sendai virus vectors [145], episomal vetors [146] and excisable piggyBac vectors [147]. DNA-free reprogramming methods, including messenger RNA [148] and proteins $[149,150]$, have also proven efficient and are often preferred as they are transitory methods and are eliminated rapidly. In contrast, NPC and DANs derived from hiPSC generated using lentiviruses exhibit residual expression of exogenous reprogramming genes. Furthermore, a protein-based reprogramming method leads to more robust hiPSC that are highly expandable without senescence [21]. Vector- and transgene-free hiPSC-NPCs were transplanted into a model of stroke [30] or PD [21,24]. No tumor formation was observed for up to 12 months post-transplantation. 


\subsubsection{The Epigenetic Landscape of Induced Pluripotent Stem Cells}

To acquire pluripotency, a somatic cell needs to be reprogrammed from a differentiated state into a permissive state similar to the early embryo. During this process of reprogramming, the genome may permanently be altered through aberrant imprinting, activation of endogenous retroviruses [151], and incomplete reprogramming.

IPSC derived by reprogramming show DNA methylation signatures similar to their somatic tissue of origin, which promote their differentiation into lineages related to the donor cell and restrict their participation to other cell fates [152-154]. Reprogramming also generate aberrant differential methylation (often a reduction in DNA methylation) differing from the somatic donor cell or hESC [153]. In general, hiPSC retain their specific epigenetic signature across differentiation and as a result, were reported to have impaired differentiation potential compared to hESC [152,153,155]. While prolonged expansion of iPSC in culture can reset iPSC and allows the loss of this epigenetic memory [156], extended culturing also promotes the accumulation of genetic defects as discussed previously, and induces other epigenetic abnormalities such as chromosome $\mathrm{X}$ erosion in female hPSC $[157,158]$. In addition to causing differentiation defects, epigenetic alterations can confer a proliferative advantage to the cells, due for example to an increased expression of oncogenes located on the reactivated chromosome X [159], and potentially pose additional risks of cancer for the clinical application of hiPSC.

\subsubsection{Immune Rejection}

A crucial step toward successful clinical application of hPSC is to overcome the immune response that may be evoked by their transplantation. Since their groundbreaking discovery by Shinya Yamanaka in 2006, iPSC have revolutionized regenerative medicine. In addition to avoiding the ethical concerns linked to the destruction of human embryos, the main advantage of hiPSC over hESC is that they can be derived directly from the patients themselves and be used for autologous cell replacement therapy. Unlike an allogenic graft using hESC, autologous transplantation with hiPSC would, in theory, elicit negligible immune response, eliminating the risk of graft rejection.

IPSC immunogenicity was not initially questioned as it seemed obvious that the reprogrammed iPSC carried the same markers of immunogenicity that they expressed in their original somatic state. Zhao et al., 2011 were the first to investigate the matter by testing the immunological reactions triggered by auto-graft of undifferentiated mouse and human iPSC in syngenic or humanized mice respectively $[160,161]$. Although autologous cells were generally assumed to be immune-tolerated by the recipient they originally came from, an unexpected immune response to teratomas formed from autologous murine or human iPSC (but not mESC) was reported and associated with an infiltration of T lymphocytes and necrosis [160]. Similarly, transplantation of autologous hiPSC-derived smooth muscle cells (SMCs) into skeletal muscles of humanized mice triggered an immunogenic response and resulted in T cells infiltration of the graft, while autologous hiPSC-derived retinal pigment epithelial (RPE) cells were well tolerated and showed low immunogenicity both in the eyes and skeletal muscles [161]. Because integration-free methods were used for reprogramming, immune-rejection could not be caused by malignant transformation due to vector integration. These results initially raised serious doubts about the possible use of hiPSC in regenerative medicine.

However, many studies have since counterbalanced this initial observation. Immunogenicity of endothelial, hepatocyte and neuronal cells derived from ESC and iPSC was tested by assessing cytotoxic $\mathrm{T}$ lymphocyte response in vitro and in vivo after transplantation in syngeneic mice. No immune response to syngeneic iPSC was observed [162]. Similarly, differentiated skin and bone marrow tissues derived from mouse iPSC showed no difference in the success rate of transplantation when compared to mouse ESC-derived tissues. Furthermore, no immune response, including $\mathrm{T}$ cell infiltration, was observed for tissues derived from syngeneic iPSC or ESC [163]. These results were further confirmed by the successful transplantation of porcine iPSC-NPC into the spinal cord of syngeneic mini-pigs in the absence of immunosuppression. Long-term survival with neuronal and 
glial differentiation and no immune rejection of the transplanted cells were noted [164]. More recently, patient-derived hiPSC-DAN progenitors were shown to trigger immune rejection after transplantation into allogenic humanized mice, but showed absence of immunogenicity when transplanted into patient-humanized (using the patient's peripheral blood mononuclear cells) mice [7].

Several mechanisms such as epigenetic and genetic instability in hiPSC could explain immune responses in transplant recipients even when differentiated cells are transplanted. A host immune response (T-cell infiltration) to hiPSC appears to be dependent on the antigenic profile of the transplant. Misexpression of immunogenic antigens, Zg16 and Hormad1, was found in hiPSC-derived SMCs, but not in hiPSC-derived RPEs, and potentially explains the disparity in immunogenicity of these two hiPSC derivatives after transplantation in humanized mice [161]. First, epigenetic abnormalities observed in hiPSC could lead to abnormal expression of immunogenic proteins during specific lineage differentiation of hiPSCs but not hESCs. Second, genomic translocation or point mutations acquired during the process of reprogramming could create new immunogenic determinants. Importantly, despite the controversy, the lack of immunogenicity of hiPSC-derived cells has been confirmed in the patient who received his own hiPSC-derived RPE to treat macular degeneration [4] and in the Parkinson's patient who was transplanted with his own hiPSC-DAN progenitors [7].

Many practical concerns arise with autologous transplantation. Autologous hiPSC-cell therapies are labour-intensive and a highly time-consuming process. The time pressure often associated with treating conditions such as severe SCI or stroke is incompatible with the time required to perform personalized stem cell work (e.g., derivation of hiPSC from the patient, cell banking, and differentiation into the relevant cell type). Early neuronal transplantation following SCI is indeed very beneficial as it can potentially avoid secondary injury and enhances recovery [48,49]. The use of allogeneic hiPSC/hESC lines for subsequent administration into SCI patients is therefore likely more feasible. Another concern is the disease status of the donor cells from patients who have disease-specific genetic backgrounds. To avoid disease recurrence, the disease-causing mutation would need to be corrected in hPSC prior to transplantation, or allogeneic transplantation may also become the preferred option for genetic degenerative diseases.

In contrast to hiPSC, an allogenic graft using hESC would incontestably require some form of pharmacological immunosuppression to avoid rejection by the recipient's immune system. Long term immunosuppression comes with risks of infections and cancer and may lead to serious complications such as cardiovascular diseases [165]. The highly polymorphic major histocompatibility complex (MHC), known as HLA (Human Leukocyte Antigen) Class I and II in human, allows the immune system to recognize the body's own cells and target foreign elements. HESCs express low level of HLA class I but not class II molecules. It has first been suggested that hESCs possess unique immune-privileged characteristics as they have a considerably weaker capacity to stimulate $\mathrm{T}$ cells compared with other graft types and can evade immune allo-rejection [166,167]. However, allogeneic NK cells can eliminate human ESCs in vitro and in vivo [137,168]. Secondly, following transplantation hESC will undergo differentiation into various cell types that express HLA molecules, leading to robust T-dependent allogeneic rejection.

In organ transplantation, matching HLA-A, -B, and -DR, improves the graft survival rates [169] and could represent a promising approach to reduce the use of immunosuppressant drugs in hPSC transplantation procedures. However, matching HLA types between donors and recipients is notoriously difficult. One way to produce HLA matched cells for cell-based therapy is by using histocompatible hPSC with homozygous HLA loci. This strategy not only significantly reduces the possibility of the derived cells being rejected by the recipient's immune system but also makes a single cell line suitable for millions of patients. A relatively small number of HLA homozygous lines could be sufficient to provide immune matched cells to a large percentage of the world's population. It is estimated that by selecting those homozygous for the 10 most frequent HLA-A,$\mathrm{B}$, or -DRB1 haplotypes, 10, 75, and 140 HLA-homozygous iPSC lines would match approximately $50 \%, 80 \%$, and $90 \%$ of the Korean/Japanese population, respectively [170,171]. This strategy would 
be more challenging for populations with higher racial and genetic diversity such as the US. A bank of 100 hiPSC lines homozygous for the most frequent HLA in each population could match up to $88 \%$ of European Americans, $63 \%$ of Asian Americans, $52 \%$ of Hispanic Americans and $45 \%$ only of African American [172]. Allele-specific HLA targeting was also performed in heterozygous hiPSC to generate pseudo-homozygous HLA hiPSC that could reduce the number of donors needed for HLA matching [173]. MHC matching was tested for dopaminergic transplants in NHPs and was able to reduce the immune response and improve engraftment of the transplant [174]. This idea has however been recently challenged. In the absence of immunosuppression, MHC matching alone is insufficient to prevent long-term rejection of iPSC-derived neuronal grafts in the lesioned brain of NHP [175]. Similarly, although the immunogenicity of allogeneic iPSC-cardiomyocytes (CMs) was reduced by MHC-matching, it was not completely abolished and an appropriate level of immunosuppression was required for successful engraftment in the heart of macaques [176].

As an alternative, a number of groups have set out to generate universal stem cells capable of evading any patient's immune system. These approaches consist of manipulating genes that encode for HLA I and II proteins [173,177-179]. While ablation of HLA class II can be achieved by targeting its transcriptional master regulator CIITA, disruption of the Beta-2Microglobulin (B2M) gene eliminates surface expression of all HLA class Ia and $b$ molecules and prevent the cells from being recognized as allogeneic by CD8+ T cells. However, B2M KO hPSC become vulnerable to NK cell-mediated rejection through missing-self response. Forced expression of minimally polymorphic HLA-E is one way to confer resistance to NK cells when HLA I is removed [180]. Individual deletion of the highly polymorphic HLA class Ia (HLA-A,-B,-C) genes represent another strategy to protect the donor cells from $\mathrm{CD}^{+} \mathrm{T}$ cell-mediated cytotoxicity without losing the HLA class Ib (non-polymorphic HLA-E,-G) protective function against NK cells mediated lysis $[173,179]$. Over-expression of PDL1 and CD47 also confers an additional advantage by protecting cells from $\mathrm{T}$ cell rejection and preventing macrophage engulfment respectively $[177,179]$. Engineered hypo-immunogenic hPSC showed reduced immune rejection in vivo, unlocking their full potential for regenerative medicine.

\subsection{Regeneration of the Central Nervous System}

In humans, or in mammals in general, the adult CNS has a limited regenerative capacity and is unable to fully restore its function after injury. Consequently, CNS trauma generally results in severe and persistent functional deficits which drastically reduce quality of life. This regeneration failure is mainly due to the very limited number of neural stem cells that the CNS retains into adulthood, which prevents the replacement of lost neurons, and to its low capacity to repair damaged neurons. Human brains, in particular, are controversially reported to have limited or no adult de novo neurogenesis [181-183]. The adult CNS also shows limited axonal regeneration which results from the lack of intrinsic growth capability of existing neurons (due to insufficient growth promoting signals) and an inhibitory CNS microenvironment.

\subsubsection{CNS Microenvironment}

The non-permissive nature of the CNS environment for axonal regeneration is largely attributable to non-neuronal components of the CNS [184], in particular the neurite growth inhibitory myelin proteins secreted by oligodendrocytes.

Lesions in the CNS cause changes in the microenvironment directly surrounding the site of the injury. Myelin, a lipid-rich substance normally insulating the axons, becomes severely damaged and leaves the axons exposed and vulnerable to myelin-derived inhibitory molecules such as Nogo, myelin-associated glycoprotein (MAG), and oligodendrocyte-myelin glycoprotein (OMgp). Nogo-A is considered to be the major inhibitor of axonal regeneration and is thought to launch a signaling cascade which induces cytoskeletal changes and destabilization in the growth cones [185]. Its expression varies greatly after SCI, initially decreasing the first 3 days to reach a peak after 7 days. High levels of Nogo-A may be required for its inhibitory action. The fluctuation in expression of Nogo-A suggests a 
7-day window for treatment of SCI $[186,187]$. Current approaches have focused on administration of Nogo-receptor blocking peptides and anti-NogoA blocking antibodies to promote axon regeneration in rodent and primate models of SCI. Neutralization of the neurite growth inhibitor Nogo-A by intrathecal antibodies has shown enhanced functional recovery and regeneration of injured CNS in SCI rats [188].

Another critical component of the limited regenerative potential of the adult CNS is neuro-inflammation. In addition to severed axons, trauma to the spinal cord causes blood-spinal cord barrier disruption, which in turn causes localized neuronal death. This induces further oxidative stress and glutamate release causing excitotoxic death of neighboring neurons and glia. Shortly after the injury, resident microglia become reactivated, initiating a robust immune response by secreting various cytokines, and peripheral macrophages are recruited to the lesion site. This inflammatory response may have additional deleterious effect on neuronal regeneration and prevent functional recovery. Depletion of peripheral macrophages [189] and administration of the anti-inflammatory drug minocycline [190] have been shown to enhance axonal regeneration and improve functional recovery after SCI. However, a beneficial role of neuro-inflammation has also been described. Macrophage/microglia activation, by intraspinal injection of pro-inflammatory molecules, results in a better regenerative outcome after SCI, either by promoting sectioned axons regrowth [191] or reducing axonal loss [192]. These conflicting results have led to considerable debate concerning the neurotoxic or neuroprotective effect of inflammation in CNS regeneration.

Because of the importance of the immune component in CNS regeneration, caution is necessary in translating preclinical models of neurodegenerative diseases to human. As discussed previously, functional recovery following transplantation of various hES/hiPS cell-derived neural cell types has been well reported in rodents with SCI, PD, stroke or MS. However, in most cases, transplantations were tested in immune-deficient animals and cannot translate directly to human patients. Interestingly, unlike successful studies performed in immuno-deficient mice, the transplantation of hiPSC-NPCs in immuno-competent SCI mice treated with tacrolimus (an immunosuppressive drug) led to very disappointing results. Behavioral assessment showed failure to improve functional recovery and overall poor long-term survival [43]. Whether the discrepancy in the results can be attributed to the difference in immunocompetency of the mouse models is unclear but would benefit from further investigation. Similarly, chronic neuropathic pain cell therapy studies used immunosuppressed animals $[50,51]$ which may affect the results. Whilst transplantation studies using syngenic fetal mouse material suggest this will not affect analgesia, given the important role of immune cells in pain pathogenesis $[193,194]$ or CNS regeneration, further investigation is needed to establish the potential effect of immunosuppression.

\subsubsection{Glial Scarring}

The glial scar is one of the most established barriers of CNS regeneration. The glial scar has been largely studied in the context of SCI, but also occurs after traumatic brain injury or ischemic stroke and in neurodegenerative diseases such as $\mathrm{AD}$, or in demyelinating and inflammatory pathologies such as MS.

As discussed previously, damage to the spinal cord is followed by an acute inflammatory response. Resident microglia are activated, and peripheral immune cells (including macrophages and lymphocytes) enter the lesion site. This inflammatory reaction eventually becomes chronic and at this point, astrocytes proliferate, hypertrophy and overlap to contain the damage and isolate the lesion from the spared tissue, forming a regeneration-inhibiting glial scar. The repressive nature of the glial scar has been largely attributed to a high concentration of ECM (extra-cellular matrix) and inhibitory proteins, including myelin-associated chondroitin sulfate proteoglycans (CSPGs) secreted by astrocytes [195]. CPSGs have been described to impair neuronal growth in vitro by signaling through the Rho/ROCK pathway [196]. Degradation of CSPGs using chondriotinase enzyme was sufficient to restore synaptic activity below the lesion site in SCI rats [197] and promoted functional recovery following SCI $[198,199]$. Similarly, an increase of CSPG concentration caused a decrease in neurite 
length in vitro [200]. Other cell types implicated in glial scarring include pericytes. The inhibition of pericytes proliferation following SCI was recently shown to enhance neuronal survival, cause a reduction in glial scar formation and improve functional recovery after SCI [201].

Conversely, a beneficial role of the glial scar has also been described. By preventing resident astrocytes from proliferating after SCI (using conditional genetic ablation), recovery from spinal cord lesions was reduced. The injured area in the spinal cord expanded, more axons were severed and an increased neuronal death was observed in mice unable to generate glial scars. This study also demonstrated that astrocytes of the glial scar are a major source of neurotrophic factors (CNTF, HGF, IGF1) required for the survival of neurons adjacent to the lesion after SCI [202]. Furthermore, a supportive role of the glial scar in regeneration of neurons has also recently been identified. Preventing astrocytic scar formation, by selectively killing proliferative scar-forming astrocytes or deleting of STAT3 signaling specifically in astrocytes, stopped stimulated axon regrowth in mice. Prevention of the scarring does not reduce overall CSPG production post-injury, due to the quantity of non-astrocytic cells producing CSPGs [203]. The astrocytic glial scar has also been recently shown to not prevent remyelination in a rat model of MS [204]. These results demonstrate the importance of apparently growth inhibiting programs in reacting to CNS damage appropriately, and highlight a tightly regulated mechanism that leads to successful repair.

\section{Conclusions}

Over the past decades, neurodegenerative diseases and nervous system injury have been a major focus of regenerative medicine, with many studies dedicated to developing efficient and clinically relevant hPSC replacement therapies for the treatment of a variety of neurological disorders. However, the clinical feasibility of these therapies requires further assessment. A deeper understanding of differentiation pathways and mechanisms will permit the development of defined cell populations that can be used as more potent therapeutics. Moreover, the increased risk of cancer caused by the use of hiPSCs raised serious reservations regarding the development of autologous cell therapies. Future directions will concentrate on banking clinically safe and universally compatible hPSC to overcome the challenge of immune rejection. Nonetheless, hPSC therapies provide genuine hope for a wide range of currently devastating degenerative diseases, and will eventually change the way we see aging and the associated tissue degeneration by redefining the impossible.

Author Contributions: L.C., E.F., J.P., J.M. wrote the manuscript; T.R. and M.W. made the figures; L.C., G.G.N. conceived of and supervised the work and all authors contributed to editing. All authors have read and agreed to the published version of the manuscript.

Funding: L.C. is supported by a Anne and John Chong Fellowship and G.N. is funded by National Health and Medical Research Council (NHMRC) project grants APP1107514, APP1158164, APP1158165 and the NSW Ministry of Health.

Acknowledgments: We acknowledge Servier Medical Art for providing the schematics for the figures, under the C.C. 3.0 license. Images are available at https://smart.servier.com/. The graphical abstract was created with BioRender.com.

Conflicts of Interest: L.C., J.M. and G.G.N. are listed as inventors on a patent relating to the use of stem cells for neuropathic pain treatment. The other authors declare that they have no conflict of interests. The funders had no role in the design of the study; in the writing of the manuscript or in the decision to publish.

\section{References}

1. Schwartz, S.D.; Hubschman, J.-P.; Heilwell, G.; Franco-Cardenas, V.; Pan, C.K.; Ostrick, R.M.; Mickunas, E.; Gay, R.; Klimanskaya, I.; Lanza, R. Embryonic stem cell trials for macular degeneration: A preliminary report. Lancet 2012, 379, 713-720. [CrossRef] [PubMed]

2. Schwartz, S.D.; Regillo, C.D.; Lam, B.L.; Eliott, D.; Rosenfeld, P.J.; Gregori, N.Z.; Hubschman, J.-P.; Davis, J.L.; Heilwell, G.; Spirn, M.; et al. Human embryonic stem cell-derived retinal pigment epithelium in patients with age-related macular degeneration and Stargardt's macular dystrophy: Follow-up of two open-label phase 1/2 studies. Lancet 2015, 385, 509-516. [CrossRef] [PubMed] 
3. Song, W.K.; Park, K.-M.; Kim, H.-J.; Lee, J.H.; Choi, J.; Chong, S.Y.; Shim, S.H.; Del Priore, L.V.; Lanza, R. Treatment of Macular Degeneration Using Embryonic Stem Cell-Derived Retinal Pigment Epithelium: Preliminary Results in Asian Patients. Stem Cell Rep. 2015, 4, 860-872. [CrossRef]

4. Mandai, M.; Watanabe, A.; Kurimoto, Y.; Hirami, Y.; Morinaga, C.; Daimon, T.; Fujihara, M.; Akimaru, H.; Sakai, N.; Shibata, Y.; et al. Autologous Induced Stem-Cell-Derived Retinal Cells for Macular Degeneration. N. Engl. J. Med. 2017, 376, 1038-1046. [CrossRef] [PubMed]

5. Boldt, H.C.; Bressler, S.B.; Fine, S.L.; Bressler, N.M. Age-related macular degeneration. Curr. Opin. Ophthalmol. 1990, 1, 247-257. [CrossRef]

6. Lindvall, O.; Brundin, P.; Widner, H.; Rehncrona, S.; Gustavii, B.; Frackowiak, R.S.; Leenders, K.L.; Sawle, G.V.; Rothwell, J.C.; Marsden, C.D.; et al. Grafts of fetal dopamine neurons survive and improve motor function in Parkinson's disease. Science 1990, 247, 574-577. [CrossRef]

7. Schweitzer, J.S.; Song, B.; Herrington, T.M.; Park, T.-Y.; Lee, N.; Ko, S.; Jeon, J.; Cha, Y.; Kim, K.; Li, Q.; et al. Personalized iPSC-Derived Dopamine Progenitor Cells for Parkinson's Disease. N. Engl. J. Med. 2020, 382, 1926-1932. [CrossRef]

8. Tsuji, O.; Sugai, K.; Yamaguchi, R.; Tashiro, S.; Nagoshi, N.; Kohyama, J.; Iida, T.; Ohkubo, T.; Itakura, G.; Isoda, M.; et al. Concise Review: Laying the Groundwork for a First-In-Human Study of an Induced Pluripotent Stem Cell-Based Intervention for Spinal Cord Injury. Stem Cells 2019, 37, 6-13. [CrossRef]

9. Merkle, F.T.; Ghosh, S.; Kamitaki, N.; Mitchell, J.; Avior, Y.; Mello, C.; Kashin, S.; Mekhoubad, S.; Ilic, D.; Charlton, M.; et al. Human pluripotent stem cells recurrently acquire and expand dominant negative P53 mutations. Nat. Cell Biol. 2017, 545, 229-233. [CrossRef]

10. Raza, C.; Anjum, R.; Shakeel, N.U.A. Parkinson's disease: Mechanisms, translational models and management strategies. Life Sci. 2019, 226, 77-90. [CrossRef]

11. Poewe, W. Treatments for Parkinson disease-past achievements and current clinical needs. Neurology 2009, 72, 65-73. [CrossRef]

12. Figge, D.A.; Jaunarajs, K.L.E.; Standaert, D.G. Dynamic DNA Methylation Regulates Levodopa-Induced Dyskinesia. J. Neurosci. 2016, 36, 6514-6524. [CrossRef] [PubMed]

13. Roy, N.S.; Cleren, C.; Singh, S.K.; Yang, L.; Beal, M.F.; Goldman, S.A. Functional engraftment of human ES cell-derived dopaminergic neurons enriched by coculture with telomerase-immortalized midbrain astrocytes. Nat. Med. 2006, 12, 1259-1268. [CrossRef] [PubMed]

14. Doi, D.; Morizane, A.; Kikuchi, T.; Onoe, H.; Hayashi, T.; Kawasaki, T.; Motono, M.; Sasai, Y.; Saiki, H.; Gomi, M.; et al. Prolonged Maturation Culture Favors a Reduction in the Tumorigenicity and the Dopaminergic Function of Human ESC-Derived Neural Cells in a Primate Model of Parkinson's Disease. Stem Cells 2012, 30, 935-945. [CrossRef] [PubMed]

15. Kriks, S.; Shim, J.-W.; Piao, J.; Ganat, Y.M.; Wakeman, D.R.; Xie, Z.; Carrillo-Reid, L.; Auyeung, G.; Antonacci, C.; Buch, A.; et al. Dopamine neurons derived from human ES cells efficiently engraft in animal models of Parkinson's disease. Nat. Cell Biol. 2011, 480, 547-551. [CrossRef]

16. Kirkeby, A.; Grealish, S.; Wolf, D.A.; Nelander, J.; Wood, J.; Lundblad, M.; Lindvall, O.; Parmar, M. Generation of Regionally Specified Neural Progenitors and Functional Neurons from Human Embryonic Stem Cells under Defined Conditions. Cell Rep. 2012, 1, 703-714. [CrossRef]

17. Grealish, S.; Diguet, E.; Kirkeby, A.; Mattsson, B.; Heuer, A.; Bramoulle, Y.; Van Camp, N.; Perrier, A.L.; Hantraye, P.; Björklund, A.; et al. Human ESC-Derived Dopamine Neurons Show Similar Preclinical Efficacy and Potency to Fetal Neurons when Grafted in a Rat Model of Parkinson's Disease. Cell Stem Cell 2014, 15, 653-665. [CrossRef]

18. Gantner, C.W.; De Luzy, I.R.; Kauhausen, J.A.; Moriarty, N.; Niclis, J.C.; Bye, C.R.; Penna, V.; Hunt, C.P.; Ermine, C.M.; Pouton, C.W.; et al. Viral Delivery of GDNF Promotes Functional Integration of Human Stem Cell Grafts in Parkinson's Disease. Cell Stem Cell 2020, 26, 511-526.e5. [CrossRef]

19. Hargus, G.; Cooper, O.; Deleidi, M.; Levy, A.; Lee, K.N.; Marlow, E.; Yow, A.; Soldner, F.; Hockemeyer, D.; Hallett, P.J.; et al. Differentiated Parkinson patient-derived induced pluripotent stem cells grow in the adult rodent brain and reduce motor asymmetry in Parkinsonian rats. Proc. Natl. Acad. Sci. USA 2010, 107, 15921-15926. [CrossRef]

20. Kikuchi, T.; Morizane, A.; Doi, D.; Okita, K.; Nakagawa, M.; Yamakado, H.; Inoue, H.; Takahashi, R.; Takahashi, J. Idiopathic Parkinson's disease patient-derived induced pluripotent stem cells function as midbrain dopaminergic neurons in rodent brains. J. Neurosci. Res. 2017, 95, 1829-1837. [CrossRef] 
21. Rhee, Y.-H.; Ko, J.-Y.; Chang, M.-Y.; Yi, S.-H.; Kim, D.; Kim, C.-H.; Shim, J.-W.; Jo, A.-Y.; Kim, B.-W.; Lee, $\mathrm{H}$.; et al. Protein-based human iPS cells efficiently generate functional dopamine neurons and can treat a rat model of Parkinson disease. J. Clin. Investig. 2011, 121, 2326-2335. [CrossRef] [PubMed]

22. Han, F.; Wang, W.; Chen, B.; Chen, C.; Li, S.; Lu, X.; Duan, J.; Zhang, Y.; Zhang, Y.A.; Guo, W.; et al. Human induced pluripotent stem cell-derived neurons improve motor asymmetry in a 6-hydroxydopamine-induced rat model of Parkinson's disease. Cytotherapy 2015, 17, 665-679. [CrossRef] [PubMed]

23. Kikuchi, T.; Morizane, A.; Doi, D.; Onoe, H.; Hayashi, T.; Kawasaki, T.; Saiki, H.; Miyamoto, S.; Takahashi, J. Survival of Human Induced Pluripotent Stem Cell-Derived Midbrain Dopaminergic Neurons in the Brain of a Primate Model of Parkinson's Disease. J. Park. Dis. 2011, 1, 395-412. [CrossRef]

24. Kikuchi, T.; Morizane, A.; Doi, D.; Magotani, H.; Onoe, H.; Hayashi, T.; Mizuma, H.; Takara, S.; Takahashi, R.; Inoue, H.; et al. Human iPS cell-derived dopaminergic neurons function in a primate Parkinson's disease model. Nat. Cell Biol. 2017, 548, 592-596. [CrossRef]

25. Oki, K.; Tatarishvili, J.; Woods, J.; Koch, P.; Wattananit, S.; Mine, Y.; Monni, E.; Tornero, D.; Ahlenius, H.; Ladewig, J.; et al. Human-Induced Pluripotent Stem Cells form Functional Neurons and Improve Recovery After Grafting in Stroke-Damaged Brain. Stem Cells 2012, 30, 1120-1133. [CrossRef] [PubMed]

26. Tornero, D.; Tsupykov, O.; Granmo, M.; Rodriguez, C.; Grønning-Hansen, M.; Thelin, J.; Smozhanik, E.; Laterza, C.; Wattananit, S.; Ge, R.; et al. Synaptic inputs from stroke-injured brain to grafted human stem cell-derived neurons activated by sensory stimuli. Brain 2017, 140, 692-706. [CrossRef]

27. Tornero, D.; Wattananit, S.; Madsen, M.G.; Koch, P.; Wood, J.; Tatarishvili, J.; Mine, Y.; Ge, R.; Monni, E.; Devaraju, K.; et al. Human induced pluripotent stem cell-derived cortical neurons integrate in stroke-injured cortex and improve functional recovery. Brain 2013, 136, 3561-3577. [CrossRef]

28. Palma-Tortosa, S.; Tornero, D.; Hansen, M.G.; Monni, E.; Hajy, M.; Kartsivadze, S.; Aktay, S.; Tsupykov, O.; Parmar, M.; Deisseroth, K.; et al. Activity in grafted human iPS cell-derived cortical neurons integrated in stroke-injured rat brain regulates motor behavior. Proc. Natl. Acad. Sci. USA 2020, 117, 9094-9100. [CrossRef]

29. Gomi, M.; Takagi, Y.; Morizane, A.; Doi, D.; Nishimura, M.; Miyamoto, S.; Takahashi, J. Functional recovery of the murine brain ischemia model using human induced pluripotent stem cell-derived telencephalic progenitors. Brain Res. 2012, 1459, 52-60. [CrossRef]

30. Mohamad, O.; Drury-Stewart, D.; Song, M.; Faulkner, B.; Chen, D.; Yu, S.P.; Wei, L. Vector-Free and Transgene-Free Human iPS Cells Differentiate into Functional Neurons and Enhance Functional Recovery after Ischemic Stroke in Mice. PLoS ONE 2013, 8, e64160. [CrossRef]

31. Chang, D.-J.; Lee, N.; Park, I.-H.; Choi, C.; Jeon, I.; Kwon, J.; Oh, S.-H.; Shin, D.A.; Tae, J.; Lee, N.R.; et al. Therapeutic Potential of Human Induced Pluripotent Stem Cells in Experimental Stroke. Cell Transplant. 2013, 22, 1427-1440. [CrossRef] [PubMed]

32. Hermanto, Y.; Sunohara, T.; Faried, A.; Takagi, Y.; Takahashi, J.; Maki, T.; Miyamoto, S. Transplantation of feeder-free human induced pluripotent stem cell-derived cortical neuron progenitors in adult male Wistar rats with focal brain ischemia. J. Neurosci. Res. 2017, 96, 863-874. [CrossRef]

33. Baker, E.W.; Platt, S.R.; Lau, V.W.; Grace, H.E.; Holmes, S.P.; Wang, L.; Duberstein, K.J.; Howerth, E.W.; Kinder, H.A.; Stice, S.L.; et al. Induced Pluripotent Stem Cell-Derived Neural Stem Cell Therapy Enhances Recovery in an Ischemic Stroke Pig Model. Sci. Rep. 2017, 7, 1-15. [CrossRef]

34. Cunningham, M.; Cho, J.-H.; Leung, A.; Savvidis, G.; Ahn, S.; Moon, M.; Lee, P.K.; Han, J.J.; Azimi, N.; Kim, K.-S.; et al. hPSC-Derived Maturing GABAergic Interneurons Ameliorate Seizures and Abnormal Behavior in Epileptic Mice. Cell Stem Cell 2014, 15, 559-573. [CrossRef] [PubMed]

35. Anderson, N.C.; Van Zandt, M.A.; Shrestha, S.; Lawrence, D.B.; Gupta, J.; Chen, C.Y.; Harrsch, F.A.; Boyi, T.; Dundes, C.E.; Aaron, G.; et al. Pluripotent stem cell-derived interneuron progenitors mature and restore memory deficits but do not suppress seizures in the epileptic mouse brain. Stem Cell Res. 2018, 33, 83-94. [CrossRef] [PubMed]

36. Fujiwara, N.; Shimizu, J.; Takai, K.; Arimitsu, N.; Saito, A.; Kono, T.; Umehara, T.; Ueda, Y.; Wakisaka, S.; Suzuki, T.; et al. Restoration of spatial memory dysfunction of human APP transgenic mice by transplantation of neuronal precursors derived from human iPS cells. Neurosci. Lett. 2013, 557, 129-134. [CrossRef] [PubMed]

37. Yue, W.; Li, Y.; Zhang, T.; Jiang, M.; Qian, Y.; Zhang, M.; Sheng, N.; Feng, S.; Tang, K.; Yu, X.; et al. ESC-Derived Basal Forebrain Cholinergic Neurons Ameliorate the Cognitive Symptoms Associated with Alzheimer's Disease in Mouse Models. Stem Cell Rep. 2015, 5, 776-790. [CrossRef] 
38. Takamatsu, K.; Ikeda, T.; Haruta, M.; Matsumura, K.; Ogi, Y.; Nakagata, N.; Uchino, M.; Ando, Y.; Nishimura, Y.; Senju, S. Degradation of amyloid beta by human induced pluripotent stem cell-derived macrophages expressing Neprilysin-2. Stem Cell Res. 2014, 13, 442-453. [CrossRef]

39. Wang, S.; Bates, J.; Li, X.; Schanz, S.; Chandler-Militello, D.; Levine, C.; Maherali, N.; Studer, L.; Hochedlinger, K.; Windrem, M.; et al. Human iPSC-Derived Oligodendrocyte Progenitor Cells Can Myelinate and Rescue a Mouse Model of Congenital Hypomyelination. Cell Stem Cell 2013, 12, 252-264. [CrossRef]

40. Douvaras, P.; Wang, J.; Zimmer, M.; Hanchuk, S.; O’Bara, M.A.; Sadiq, S.; Sim, F.J.; Goldman, J.; Fossati, V. Efficient Generation of Myelinating Oligodendrocytes from Primary Progressive Multiple Sclerosis Patients by Induced Pluripotent Stem Cells. Stem Cell Rep. 2014, 3, 250-259. [CrossRef]

41. Nori, S.; Okada, Y.; Yasuda, A.; Tsuji, O.; Takahashi, Y.; Kobayashi, Y.; Fujiyoshi, K.; Koike, M.; Uchiyama, Y.; Ikeda, E.; et al. Grafted human-induced pluripotent stem-cell-derived neurospheres promote motor functional recovery after spinal cord injury in mice. Proc. Natl. Acad. Sci. USA 2011, 108, 16825-16830. [CrossRef] [PubMed]

42. Fujimoto, Y.; Abematsu, M.; Falk, A.; Tsujimura, K.; Sanosaka, T.; Juliandi, B.; Semi, K.; Namihira, M.; Komiya, S.; Smith, A.; et al. Treatment of a Mouse Model of Spinal Cord Injury by Transplantation of Human Induced Pluripotent Stem Cell-Derived Long-Term Self-Renewing Neuroepithelial-Like Stem Cells. Stem Cells 2012, 30, 1163-1173. [CrossRef] [PubMed]

43. Pomeshchik, Y.; Puttonen, K.A.; Kidin, I.; Ruponen, M.; Lehtonen, S.; Malm, T.; Åkesson, E.; Hovatta, O.; Koistinaho, J. Transplanted Human Induced Pluripotent Stem Cell-Derived Neural Progenitor Cells Do Not Promote Functional Recovery of Pharmacologically Immunosuppressed Mice with Contusion Spinal Cord Injury. Cell Transplant. 2015, 24, 1799-1812. [CrossRef] [PubMed]

44. Oh, J.; Lee, K.-I.; Kim, H.-T.; You, Y.; Yoon, D.H.; Song, K.Y.; Cheong, E.; Ha, Y.; Hwang, D.-Y. Human-induced pluripotent stem cells generated from intervertebral disc cells improve neurologic functions in spinal cord injury. Stem Cell Res. Ther. 2015, 6, 125. [CrossRef] [PubMed]

45. Lu, P.; Woodruff, G.; Wang, Y.; Graham, L.; Hunt, M.; Wu, D.; Boehle, E.; Ahmad, R.; Poplawski, G.; Brock, J.; et al. Long-Distance Axonal Growth from Human Induced Pluripotent Stem Cells after Spinal Cord Injury. Neuron 2014, 83, 789-796. [CrossRef]

46. Romanyuk, N.; Amemori, T.; Turnovcova, K.; Prochazka, P.; Onteniente, B.; Sykova, E.; Jendelova, P. Beneficial Effect of Human Induced Pluripotent Stem Cell-Derived Neural Precursors in Spinal Cord Injury Repair. Cell Transplant. 2015, 24, 1781-1797. [CrossRef]

47. Kobayashi, Y.; Okada, Y.; Itakura, G.; Iwai, H.; Nishimura, S.; Yasuda, A.; Nori, S.; Hikishima, K.; Konomi, T.; Fujiyoshi, K.; et al. Pre-Evaluated Safe Human iPSC-Derived Neural Stem Cells Promote Functional Recovery after Spinal Cord Injury in Common Marmoset without Tumorigenicity. PLoS ONE 2012, 7, e52787. [CrossRef]

48. All, A.H.; Bazley, F.A.; Gupta, S.; Pashai, N.; Hu, C.; Pourmorteza, A.; Kerr, C.L. Human Embryonic Stem Cell-Derived Oligodendrocyte Progenitors Aid in Functional Recovery of Sensory Pathways following Contusive Spinal Cord Injury. PLoS ONE 2012, 7, e47645. [CrossRef]

49. All, A.H.; Mohammad-Gharibani, P.; Gupta, S.; Bazley, F.A.; Pashai, N.; Chou, B.-K.; Shah, S.; Resar, L.M.; Cheng, L.; Gearhart, J.D.; et al. Early Intervention for Spinal Cord Injury with Human Induced Pluripotent Stem Cells Oligodendrocyte Progenitors. PLoS ONE 2015, 10, e0116933. [CrossRef]

50. Fandel, T.M.; Trivedi, A.; Nicholas, C.R.; Zhang, H.; Chen, J.; Martinez, A.F.; Noble-Haeusslein, L.J.; Kriegstein, A.R. Transplanted Human Stem Cell-Derived Interneuron Precursors Mitigate Mouse Bladder Dysfunction and Central Neuropathic Pain after Spinal Cord Injury. Cell Stem Cell 2016, 19, 544-557. [CrossRef]

51. Manion, J.; Khuong, T.; Harney, D.; Littleboy, J.B.; Ruan, T.; Loo, L.; Costigan, M.; Larance, M.; Caron, L.; Neely, G.G. Human induced pluripotent stem cell-derived GABAergic interneuron transplants attenuate neuropathic pain. Pain 2020, 161, 379-387. [CrossRef] [PubMed]

52. Tiklová, K.; Nolbrant, S.; Fiorenzano, A.; Björklund, Å.; Sharma, Y.; Heuer, A.; Gillberg, L.; Hoban, D.B.; Cardoso, T.; Adler, A.F.; et al. Single cell transcriptomics identifies stem cell-derived graft composition in a model of Parkinson's disease. Nat. Commun. 2020, 11, 1-11. [CrossRef]

53. Yamakado, H.; Moriwaki, Y.; Yamasaki, N.; Miyakawa, T.; Kurisu, J.; Uemura, K.; Inoue, H.; Takahashi, M.; Takahashi, R. $\alpha$-Synuclein BAC transgenic mice as a model for Parkinson's disease manifested decreased anxiety-like behavior and hyperlocomotion. Neurosci. Res. 2012, 73, 173-177. [CrossRef] [PubMed] 
54. Barker, R.A.; Parmar, M.; Studer, L.; Takahashi, J. Human Trials of Stem Cell-Derived Dopamine Neurons for Parkinson's Disease: Dawn of a New Era. Cell Stem Cell 2017, 21, 569-573. [CrossRef]

55. Parmar, M.; Grealish, S.; Henchcliffe, C. The future of stem cell therapies for Parkinson disease. Nat. Rev. Neurosci. 2020, 21, 103-115. [CrossRef]

56. George, P.M.; Steinberg, G.K. Novel Stroke Therapeutics: Unraveling Stroke Pathophysiology and Its Impact on Clinical Treatments. Neuron 2015, 87, 297-309. [CrossRef]

57. Marei, H.E.-S.; Hasan, A.; Rizzi, R.; Althani, A.; Afifi, N.; Cenciarelli, C.; Caceci, T.; Shuaib, A. Potential of Stem Cell-Based Therapy for Ischemic Stroke. Front. Neurol. 2018, 9, 34. [CrossRef]

58. Koch, P.; Opitz, T.; Steinbeck, J.A.; Ladewig, J.; Brüstle, O. A rosette-type, self-renewing human ES cell-derived neural stem cell with potential for in vitro instruction and synaptic integration. Proc. Natl. Acad. Sci. USA 2009, 106, 3225-3230. [CrossRef]

59. Vezzani, A.; French, J.; Bartfai, T.; Baram, T.Z. The role of inflammation in epilepsy. Nat. Rev. Neurol. 2011, 7, 31-40. [CrossRef]

60. Paudel, Y.N.; Shaikh, M.F.; Shah, S.; Kumari, Y.; Othman, I. Role of inflammation in epilepsy and neurobehavioral comorbidities: Implication for therapy. Eur. J. Pharmacol. 2018, 837, 145-155. [CrossRef]

61. Devinsky, O.; Vezzani, A.; O’Brien, T.J.; Jette, N.; Scheffer, I.E.; De Curtis, M.; Perucca, P. Epilepsy. Nat. Rev. Dis. Prim. 2018, 4, 18025. [CrossRef]

62. Hamlett, E.D.; Hjorth, E.; Ledreux, A.; Gilmore, A.; Schultzberg, M.; Granholm, A.C. RvE1 treatment prevents memory loss and neuroinflammation in the Ts65Dn mouse model of Down syndrome. Glia 2020, 68, 1347-1360. [CrossRef] [PubMed]

63. Wang, D.; Zhang, J.; Jiang, W.; Cao, Z.; Zhao, F.; Cai, T.; Aschner, M.; Luo, W. The role of NLRP3-CASP1 in inflammasome-mediated neuroinflammation and autophagy dysfunction in manganese-induced, hippocampal-dependent impairment of learning and memory ability. Autophagy 2017, 13, 914-927. [CrossRef] [PubMed]

64. Ho, J.K.; Nation, D.A.; Initiative, F.T.A.D.N. Neuropsychological Profiles and Trajectories in Preclinical Alzheimer's Disease. J. Int. Neuropsychol. Soc. 2018, 24, 693-702. [CrossRef] [PubMed]

65. Blurton-Jones, M.; Kitazawa, M.; Martinez-Coria, H.; Castello, N.A.; Müller, F.-J.; Loring, J.F.; Yamasaki, T.R.; Poon, W.W.; Green, K.N.; LaFerla, F.M. Neural stem cells improve cognition via BDNF in a transgenic model of Alzheimer disease. Proc. Natl. Acad. Sci. USA 2009, 106, 13594-13599. [CrossRef] [PubMed]

66. Fouad, G.I. Stem cells as a promising therapeutic approach for Alzheimer's disease: A review. Bull. Natl. Res. Cent. 2019, 43, 52. [CrossRef]

67. Moghadam, F.H.; Alaie, H.; Karbalaie, K.; Tanhaei, S.; Esfahani, M.H.N.; Baharvand, H. Transplantation of primed or unprimed mouse embryonic stem cell-derived neural precursor cells improves cognitive function in Alzheimerian rats. Differentiation 2009, 78, 59-68. [CrossRef]

68. Games, D.; Adams, D.; Alessandrini, R.; Barbour, R.; Berthelette, P.; Blackwell, C.; Carr, T.; Clemens, J.; Donaldson, T.; Gillespie, F.; et al. Alzheimer-type neuropathology in transgenic mice overexpressing V717F beta-amyloid precursor protein. Nature 1995, 373, 523-527. [CrossRef]

69. Yue, C.; Jing, N. The promise of stem cells in the therapy of Alzheimer's disease. Transl. Neurodegener. 2015, 4, 1-5. [CrossRef]

70. Fang, Y.; Gao, T.; Zhang, B.; Pu, J. Recent Advances: Decoding Alzheimer's Disease With Stem Cells. Front. Aging Neurosci. 2018, 10, 77. [CrossRef]

71. Al-Gharaibeh, A.; Culver, R.; Stewart, A.N.; Srinageshwar, B.; Spelde, K.; Frollo, L.; Kolli, N.; Story, D.; Paladugu, L.; Anwar, S.; et al. Induced Pluripotent Stem Cell-Derived Neural Stem Cell Transplantations Reduced Behavioral Deficits and Ameliorated Neuropathological Changes in YAC128 Mouse Model of Huntington's Disease. Front. Neurosci. 2017, 11, 628. [CrossRef] [PubMed]

72. Jeon, I.; Choi, C.; Lee, N.; Im, W.; Kim, M.; Oh, S.-H.; Park, I.-H.; Kim, H.S.; Song, J. In Vivo Roles of a Patient-Derived Induced Pluripotent Stem Cell Line (HD72-iPSC) in the YAC128 Model of Huntington's Disease. Int. J. Stem Cells 2014, 7, 43-47. [CrossRef] [PubMed]

73. Oakley, H.; Cole, S.L.; Logan, S.; Maus, E.; Shao, P.; Craft, J.; Guillozet-Bongaarts, A.; Ohno, M.; Disterhoft, J.; Van Eldik, L.; et al. Intraneuronal beta-Amyloid Aggregates, Neurodegeneration, and Neuron Loss in Transgenic Mice with Five Familial Alzheimer's Disease Mutations: Potential Factors in Amyloid Plaque Formation. J. Neurosci. 2006, 26, 10129-10140. [CrossRef] [PubMed] 
74. Hu, B.-Y.; Du, Z.-W.; Zhang, S.-C. Differentiation of human oligodendrocytes from pluripotent stem cells. Nat. Protoc. 2009, 4, 1614-1622. [CrossRef]

75. Izrael, M.; Zhang, P.; Kaufman, R.; Shinder, V.; Ella, R.; Amit, M.; Itskovitz-Eldor, J.; Chebath, J.; Revel, M. Human oligodendrocytes derived from embryonic stem cells: Effect of noggin on phenotypic differentiation in vitro and on myelination in vivo. Mol. Cell. Neurosci. 2007, 34, 310-323. [CrossRef]

76. Molineaux, S.M.; Engh, H.; De Ferra, F.; Hudson, L.; Lazzarini, R.A. Recombination within the myelin basic protein gene created the dysmyelinating shiverer mouse mutation. Proc. Natl. Acad. Sci. USA 1986, 83, 7542-7546. [CrossRef]

77. Liu, Z.; Yang, Y.; He, L.; Pang, M.; Luo, C.; Liu, B.; Rong, L. High-dose methylprednisolone for acute traumatic spinal cord injury. Neurology 2019, 93, e841-e850. [CrossRef]

78. Alizadeh, A.; Dyck, S.M.; Karimi-Abdolrezaee, S. Traumatic Spinal Cord Injury: An Overview of Pathophysiology, Models and Acute Injury Mechanisms. Front. Neurol. 2019, 10, 282. [CrossRef]

79. Khazaei, M.; Ahuja, C.S.; Nakashima, H.; Nagoshi, N.; Li, L.; Wang, J.; Chio, J.; Badner, A.; Seligman, D.; Ichise, A.; et al. GDNF rescues the fate of neural progenitor grafts by attenuating Notch signals in the injured spinal cord in rodents. Sci. Transl. Med. 2020, 12, eaau3538. [CrossRef]

80. Salewski, R.P.; Mitchell, R.A.; Li, L.; Shen, C.; Milekovskaia, M.; Nagy, A.; Fehlings, M.G. Transplantation of Induced Pluripotent Stem Cell-Derived Neural Stem Cells Mediate Functional Recovery Following Thoracic Spinal Cord Injury Through Remyelination of Axons. Stem Cells Transl. Med. 2015, 4, 743-754. [CrossRef]

81. Griffiths, D. Functional imaging of structures involved in neural control of the lower urinary tract. Handb. Clin. Neurol. 2015, 130, 121-133. [CrossRef] [PubMed]

82. Jensen, T.S.; Finnerup, N.B. Allodynia and hyperalgesia in neuropathic pain: Clinical manifestations and mechanisms. Lancet Neurol. 2014, 13, 924-935. [CrossRef] [PubMed]

83. Calvo, M.; Davies, A.J.; Hébert, H.L.; Weir, G.A.; Chesler, E.J.; Finnerup, N.B.; Levitt, R.C.; Smith, B.H.; Neely, G.G.; Costigan, M.; et al. The Genetics of Neuropathic Pain from Model Organisms to Clinical Application. Neuron 2019, 104, 637-653. [CrossRef] [PubMed]

84. Scholz, J.; Finnerup, N.B.; Attal, N.; Aziz, Q.; Baron, R.; Bennett, M.I.; Benoliel, R.; Cohen, M.; Cruccu, G.; Davis, K.D.; et al. The IASP classification of chronic pain for ICD-11: Chronic neuropathic pain. Pain 2019, 160, 53-59. [CrossRef] [PubMed]

85. Moore, K.A.; Kohno, T.; Karchewski, L.A.; Scholz, J.; Baba, H.; Woolf, C.J. Partial Peripheral Nerve Injury Promotes a Selective Loss of GABAergic Inhibition in the Superficial Dorsal Horn of the Spinal Cord. J. Neurosci. 2002, 22, 6724-6731. [CrossRef]

86. Manion, J.; Waller, M.A.; Clark, T.; Massingham, J.N.; Neely, G.G. Developing Modern Pain Therapies. Front. Neurosci. 2019, 13, 1370. [CrossRef]

87. Khuong, T.M.; Neely, G.G.; Manion, J.; Oyston, L.J.; Lau, M.-T.; Towler, H.; Lin, Y.Q.; Neely, G.G. Nerve injury drives a heightened state of vigilance and neuropathic sensitization in Drosophila. Sci. Adv. 2019, 5, eaaw4099. [CrossRef]

88. Paulozzi, L.J. Opioid Analgesic Involvement in Drug Abuse Deaths in American Metropolitan Areas. Am. J. Public Heal. 2006, 96, 1755-1757. [CrossRef]

89. Walia, K.S.; Khan, E.A.; Ko, D.H.; Raza, S.S.; Khan, Y. Side Effects of Antiepileptics- A Review. Pain Pr. 2004, 4, 194-203. [CrossRef]

90. Bráz, J.; Sharif-Naeini, R.; Vogt, D.; Kriegstein, A.; Alvarez-Buylla, A.; Rubenstein, J.L.; Basbaum, A.I. Forebrain GABAergic Neuron Precursors Integrate into Adult Spinal Cord and Reduce Injury-Induced Neuropathic Pain. Neuron 2012, 74, 663-675. [CrossRef]

91. Bráz, J.M.; Wang, X.; Guan, Z.; Basbaum, A.I. Transplant-mediated enhancement of spinal cord GABAergic inhibition reverses paclitaxel-induced mechanical and heat hypersensitivity. Pain 2015, 156, 1084-1091. [CrossRef] [PubMed]

92. Savatier, P.; Lapillonne, H.; Jirmanova, L.; Vitelli, L.; Samarut, J. Analysis of the cell cycle in mouse embryonic stem cells. Methods Mol. Boil. (Cliftonn.J.) 2002, 185, 27-33.

93. Kapinas, K.; Grandy, R.; Ghule, P.; Medina, R.; Becker, K.; Pardee, A.; Zaidi, S.K.; Lian, J.; Stein, J.; Van Wijnen, A.; et al. The abbreviated pluripotent cell cycle. J. Cell. Physiol. 2013, 228, 9-20. [CrossRef] [PubMed]

94. Somay, C.; Grunt, T.; Mannhalter, C.; Dittrich, C. Relationship of myc protein expression to the phenotype and to the growth potential of HOC-7 ovarian cancer cells. Br. J. Cancer 1992, 66, 93-98. [CrossRef] 
95. Meyer, N.; Penn, L.Z. Reflecting on 25 years with MYC. Nat. Rev. Cancer 2008, 8, 976-990. [CrossRef]

96. Zhang, C.; Xu, B.; Lu, S.; Zhao, Y.; Liu, P. HN1 contributes to migration, invasion, and tumorigenesis of breast cancer by enhancing MYC activity. Mol. Cancer 2017, 16, 90. [CrossRef]

97. Nie, Z.; Hu, G.; Wei, G.; Cui, K.; Yamane, A.; Resch, W.; Wang, R.; Green, D.R.; Tessarollo, L.; Casellas, R.; et al. c-Myc Is a Universal Amplifier of Expressed Genes in Lymphocytes and Embryonic Stem Cells. Cell 2012, 151, 68-79. [CrossRef]

98. Yeo, J.-C.; Ng, H.-H. The transcriptional regulation of pluripotency. Cell Res. 2012, 23, 20-32. [CrossRef]

99. Park, I.-H.; Zhao, R.; West, J.A.; Yabuuchi, A.; Huo, H.; Ince, T.A.; Lerou, P.H.; Lensch, M.W.; Daley, G.Q. Reprogramming of human somatic cells to pluripotency with defined factors. Nat. Cell Biol. 2008, 451, 141-146. [CrossRef]

100. Takahashi, K.; Yamanaka, S. Induction of Pluripotent Stem Cells from Mouse Embryonic and Adult Fibroblast Cultures by Defined Factors. Cell 2006, 126, 663-676. [CrossRef]

101. Chang, Y.-H.; Chu, T.-Y.; Ding, D.-C. WNT/ $\beta$-Catenin signaling pathway regulates non-tumorigenesis of human embryonic stem cells co-cultured with human umbilical cord mesenchymal stem cells. Sci. Rep. 2017, 7, srep41913. [CrossRef]

102. Samardzija, C.; Quinn, M.A.; Findlay, J.K.; Eahmed, N. Attributes of Oct4 in stem cell biology: Perspectives on cancer stem cells of the ovary. J. Ovarian Res. 2012, 5, 37. [CrossRef] [PubMed]

103. Comisso, E.; Scarola, M.; Rosso, M.; Piazza, S.; Marzinotto, S.; Ciani, Y.; Orsaria, M.; Mariuzzi, L.; Schneider, C.; Schoeftner, S.; et al. OCT4 controls mitotic stability and inactivates the RB tumor suppressor pathway to enhance ovarian cancer aggressiveness. Oncogene 2017, 36, 4253-4266. [CrossRef] [PubMed]

104. Li, S.-W.; Wu, X.-L.; Dong, C.-L.; Xie, X.-Y.; Wu, J.-F.; Zhang, X. The Differential Expression of OCT4 Isoforms in Cervical Carcinoma. PLoS ONE 2015, 10, e0118033. [CrossRef]

105. Fujino, S.; Myoshi, N. Oct4 Gene Expression in Primary Colorectal Cancer Promotes Liver Metastasis. Stem Cells Int. 2019, 2019, 7896524-10. [CrossRef] [PubMed]

106. Zhou, H.; Huan, Z.; Wang, W.; Mao, Y.; Zhu, J.; Zhou, B.; Sun, J.; Zhang, X. Expression of Oct-4 is significantly associated with the development and prognosis of colorectal cancer. Oncol. Lett. 2015, 10, 691-696. [CrossRef] [PubMed]

107. Wang, G.; Zhou, H.; Gu, Z.; Gao, Q.; Shen, G. Oct4 promotes cancer cell proliferation and migration and leads to poor prognosis associated with the survivin/STAT3 pathway in hepatocellular carcinoma. Oncol. Rep. 2018, 40, 979-987. [CrossRef]

108. Fu, T.-Y.; Hsieh, I.-C.; Cheng, J.-T.; Tsai, M.-H.; Hou, Y.-Y.; Lee, J.-H.; Liou, H.-H.; Huang, S.-F.; Chen, H.-C.; Yen, L.-M.; et al. Association of OCT4, SOX2, and NANOG expression with oral squamous cell carcinoma progression. J. Oral Pathol. Med. 2016, 45, 89-95. [CrossRef]

109. Villodre, E.S.; Kipper, F.C.; Pereira, M.B.; Lenz, G. Roles of OCT4 in tumorigenesis, cancer therapy resistance and prognosis. Cancer Treat. Rev. 2016, 51, 1-9. [CrossRef]

110. Lin, J.; Zhang, L.; Huang, H.; Huang, Y.; Huang, L.; Wang, J.; Huang, S.; He, L.; Zhou, Y.; Jia, W.; et al. MiR-26b/KPNA2 axis inhibits epithelial ovarian carcinoma proliferation and metastasis through downregulating OCT. Oncotarget 2015, 6, 23793-23806. [CrossRef]

111. Lee, T.K.W.; Castilho, A.; Cheung, V.C.H.; Tang, K.H.; Ma, S.; Ng, I.O.L. CD24+ Liver Tumor-Initiating Cells Drive Self-Renewal and Tumor Initiation through STAT3-Mediated NANOG Regulation. Cell Stem Cell 2011, 9, 50-63. [CrossRef] [PubMed]

112. Palla, A.; Piazzolla, D.; Alcazar, N.; Cañamero, M.; Graña, O.; Gómez-Lopez, G.; Dominguez, O.; Dueñas, M.; Paramio, J.M.; Serrano, M. The pluripotency factor NANOG promotes the formation of squamous cell carcinomas. Sci. Rep. 2015, 5, 10205. [CrossRef] [PubMed]

113. Santaliz-Ruiz, L.E.I.; Xie, X.; Old, M.; Teknos, T.N.; Pan, Q. Emerging role of nanog in tumorigenesis and cancer stem cells. Int. J. Cancer 2014, 135, 2741-2748. [CrossRef]

114. Wuebben, E.L.; Rizzino, A. The dark side of SOX2: Cancer - a comprehensive overview. Oncotarget 2017, 8, 44917-44943. [CrossRef] [PubMed]

115. Lee, A.S.; Tang, C.; Rao, M.S.; Weissman, I.L.; Wu, J.C. Tumorigenicity as a clinical hurdle for pluripotent stem cell therapies. Nat. Med. 2013, 19, 998-1004. [CrossRef]

116. Ray, S.K. The Transcription Regulator Kruppel-Like Factor 4 and Its Dual Roles of Oncogene in Glioblastoma and Tumor Suppressor in Neuroblastoma. Forum Immunopathol. Dis. Ther. 2016, 7, 127-139. [CrossRef] 
117. Blum, B.; Benvenisty, N. The Tumorigenicity of Human Embryonic Stem Cells. Adv. Cancer Res. 2008, 100, 133-158. [CrossRef]

118. Edel, M.J.; Menchon, C.; Ménendez, S.; Consiglio, A.; Raya, A.; Belmonte, J.C.I. Rem2 GTPase maintains survival of human embryonic stem cells as well as enhancing reprogramming by regulating p53 and cyclin $D_{1}$. Genes Dev. 2010, 24, 561-573. [CrossRef]

119. Zhang, Z.-N.; Chung, S.-K.; Xu, Z.; Xu, Y. Oct4 Maintains the Pluripotency of Human Embryonic Stem Cells by Inactivating p53 Through Sirt1-Mediated Deacetylation. Stem Cells 2014, 32, 157-165. [CrossRef]

120. Kohno, S.; Kitajima, S.; Sasaki, N.; Takahashi, C. Retinoblastoma tumor suppressor functions shared by stem cell and cancer cell strategies. World J. Stem Cells 2016, 8, 170-184. [CrossRef]

121. Närvä, E.; Autio, R.; Rahkonen, N.; Kong, L.; Harrison, N.J.; Kitsberg, D.; Borghese, L.; Itskovitz-Eldor, J.; Rasool, O.; Dvorak, P.; et al. High-resolution DNA analysis of human embryonic stem cell lines reveals culture-induced copy number changes and loss of heterozygosity. Nat. Biotechnol. 2010, 28, 371-377. [CrossRef] [PubMed]

122. Nori, S.; Okada, Y.; Nishimura, S.; Sasaki, T.; Itakura, G.; Kobayashi, Y.; Renault-Mihara, F.; Shimizu, A.; Koya, I.; Yoshida, R.; et al. Long-Term Safety Issues of iPSC-Based Cell Therapy in a Spinal Cord Injury Model: Oncogenic Transformation with Epithelial-Mesenchymal Transition. Stem Cell Rep. 2015, 4, 360-373. [CrossRef]

123. Doi, D.; Samata, B.; Katsukawa, M.; Kikuchi, T.; Morizane, A.; Ono, Y.; Sekiguchi, K.; Nakagawa, M.; Parmar, M.; Takahashi, J. Isolation of Human Induced Pluripotent Stem Cell-Derived Dopaminergic Progenitors by Cell Sorting for Successful Transplantation. Stem Cell Rep. 2014, 2, 337-350. [CrossRef]

124. Lee, M.-Y.; Moon, S.H.; Jeong, H.-C.; Yi, J.-Y.; Lee, T.-H.; Shim, S.H.; Rhee, Y.-H.; Lee, S.-H.; Oh, S.-J.; Han, M.-J.; et al. Inhibition of pluripotent stem cell-derived teratoma formation by small molecules. Proc. Natl. Acad. Sci. USA 2013, 110, E3281-E3290. [CrossRef] [PubMed]

125. Okubo, T.; Iwanami, A.; Kohyama, J.; Itakura, G.; Kawabata, S.; Nishiyama, Y.; Sugai, K.; Ozaki, M.; Iida, T.; Matsubayashi, K.; et al. Pretreatment with a $\gamma$-Secretase Inhibitor Prevents Tumor-like Overgrowth in Human iPSC-Derived Transplants for Spinal Cord Injury. Stem Cell Rep. 2016, 7, 649-663. [CrossRef]

126. Cheng, F.; Ke, Q.; Chen, F.; Cai, B.; Gao, Y.; Ye, C.; Wang, D.; Zhang, L.; Lahn, B.T.; Li, W.; et al. Protecting against wayward human induced pluripotent stem cells with a suicide gene. Biomaterials 2012, 33, 3195-3204. [CrossRef]

127. Schuldiner, M.; Itskovitz-Eldor, J.; Benvenisty, N. Selective Ablation of Human Embryonic Stem Cells Expressing a "Suicide" Gene. Stem Cells 2003, 21, 257-265. [CrossRef]

128. Zhao, Q.; Lu, B.; George, S.K.; Yoo, J.J.; Atala, A. Safeguarding pluripotent stem cells for cell therapy with a non-viral, non-integrating episomal suicide construct. Biomaterials 2012, 33, 7261-7271. [CrossRef]

129. Liang, Q.; Monetti, C.; Shutova, M.V.; Neely, E.J.; Hacibekiroglu, S.; Yang, H.; Kim, C.; Zhang, P.; Li, C.; Nagy, K.; et al. Linking a cell-division gene and a suicide gene to define and improve cell therapy safety. Nat. Cell Biol. 2018, 563, 701-704. [CrossRef]

130. Qadir, M.M.F.; Álvarez-Cubela, S.; Belle, K.; Sapir, T.; Messaggio, F.; Johnson, K.B.; Umland, O.; Hardin, D.; Klein, D.; Pérez-Álvarez, I.; et al. A Double Fail-Safe Approach to Prevent Tumorigenesis and Select Pancreatic $\beta$ Cells from Human Embryonic Stem Cells. Stem Cell Rep. 2019, 12, 611-623. [CrossRef]

131. Nau, R.; Sörgel, F.; Eiffert, H. Penetration of Drugs through the Blood-Cerebrospinal Fluid/Blood-Brain Barrier for Treatment of Central Nervous System Infections. Clin. Microbiol. Rev. 2010, 23, 858-883. [CrossRef]

132. Ando, M.; Nishimura, T.; Yamazaki, S.; Yamaguchi, T.; Kawana-Tachikawa, A.; Hayama, T.; Nakauchi, Y.; Ando, J.; Ota, Y.; Takahashi, S.; et al. A Safeguard System for Induced Pluripotent Stem Cell-Derived Rejuvenated T Cell Therapy. Stem Cell Rep. 2015, 5, 597-608. [CrossRef]

133. Yagyu, S.; Hoyos, V.; Del Bufalo, F.; Brenner, M.K. An Inducible Caspase-9 Suicide Gene to Improve the Safety of Therapy Using Human Induced Pluripotent Stem Cells. Mol. Ther. 2015, 23, 1475-1485. [CrossRef] [PubMed]

134. Shi, Z.; Tchao, J.; Wu, L.; Carman, A.J. Precision installation of a highly efficient suicide gene safety switch in human induced pluripotent stem cells. Stem Cells Transl. Med. 2020, 9, 1378-1388. [CrossRef]

135. Itakura, G.; Kawabata, S.; Ando, M.; Nishiyama, Y.; Sugai, K.; Ozaki, M.; Iida, T.; Ookubo, T.; Kojima, K.; Kashiwagi, R.; et al. Fail-Safe System against Potential Tumorigenicity after Transplantation of iPSC Derivatives. Stem Cell Rep. 2017, 8, 673-684. [CrossRef] 
136. Parr, C.J.C.; Katayama, S.; Miki, K.; Kuang, Y.; Yoshida, Y.; Morizane, A.; Takahashi, J.; Yamanaka, S.; Saito, H. MicroRNA-302 switch to identify and eliminate undifferentiated human pluripotent stem cells. Sci. Rep. 2016, 6, 32532. [CrossRef]

137. Benabdallah, B.; Désaulniers-Langevin, C.; Colas, C.; Li, Y.; Rousseau, G.; Guimond, J.V.; Haddad, E.; Beauséjour, C. Natural Killer Cells Prevent the Formation of Teratomas Derived From Human Induced Pluripotent Stem Cells. Front. Immunol. 2019, 10, 2580. [CrossRef]

138. Gore, A.; Li, Z.; Fung, H.-L.; Young, J.E.; Agarwal, S.; Antosiewicz-Bourget, J.; Canto, I.; Giorgetti, A.; Israel, M.A.; Kiskinis, E.; et al. Somatic coding mutations in human induced pluripotent stem cells. Nat. Cell Biol. 2011, 471, 63-67. [CrossRef]

139. Hussein, S.M.; Batada, N.N.; Vuoristo, S.; Ching, R.W.; Autio, R.; Närvä, E.; Ng, S.; Sourour, M.; Hamalainen, R.H.; Olsson, C.; et al. Copy number variation and selection during reprogramming to pluripotency. Nat. Cell Biol. 2011, 471, 58-62. [CrossRef]

140. Perrera, V.; Martello, G. How Does Reprogramming to Pluripotency Affect Genomic Imprinting? Front. Cell Dev. Biol. 2019, 7, 76. [CrossRef]

141. Takahashi, K.; Tanabe, K.; Ohnuki, M.; Narita, M.; Ichisaka, T.; Tomoda, K.; Yamanaka, S. Induction of Pluripotent Stem Cells from Adult Human Fibroblasts by Defined Factors. Cell 2007, 131, 861-872. [CrossRef]

142. Cheng, L.; Hansen, N.F.; Zhao, L.; Du, Y.; Zou, C.; Donovan, F.X.; Chou, B.-K.; Zhou, G.; Li, S.; Dowey, S.N.; et al. Low Incidence of DNA Sequence Variation in Human Induced Pluripotent Stem Cells Generated by Nonintegrating Plasmid Expression. Cell Stem Cell 2012, 10, 337-344. [CrossRef]

143. Sugiura, M.; Kasama, Y.; Araki, R.; Hoki, Y.; Sunayama, M.; Uda, M.; Nakamura, M.; Ando, S.; Abe, M. Induced Pluripotent Stem Cell Generation-Associated Point Mutations Arise during the Initial Stages of the Conversion of These Cells. Stem Cell Rep. 2014, 2, 52-63. [CrossRef]

144. Schlaeger, T.M.; Daheron, L.; Brickler, T.R.; Entwisle, S.; Chan, K.; Cianci, A.; Devine, A.; Ettenger, A.; Fitzgerald, K.; Godfrey, M.; et al. A comparison of non-integrating reprogramming methods. Nat. Biotechnol. 2015, 33, 58-63. [CrossRef]

145. Fusaki, N.; Ban, H.; Nishiyama, A.; Saeki, K.; Hasegawa, M. Efficient induction of transgene-free human pluripotent stem cells using a vector based on Sendai virus, an RNA virus that does not integrate into the host genome. Proc. Jpn. Acad. Ser. B 2009, 85, 348-362. [CrossRef]

146. Yu, J.; Hu, K.; Smuga-Otto, K.; Tian, S.; Stewart, R.; Slukvin, I.I.; Thomson, J.A. Human Induced Pluripotent Stem Cells Free of Vector and Transgene Sequences. Science 2009, 324, 797-801. [CrossRef]

147. Woltjen, K.; Michael, I.P.; Mohseni, P.; Desai, R.; Mileikovsky, M.; Hämäläinen, R.; Cowling, R.; Wang, W.; Liu, P.; Gertsenstein, M.; et al. piggyBac transposition reprograms fibroblasts to induced pluripotent stem cells. Nat. Cell Biol. 2009, 458, 766-770. [CrossRef]

148. Warren, L.; Manos, P.D.; Ahfeldt, T.; Loh, Y.-H.; Li, H.; Lau, F.; Ebina, W.; Mandal, P.K.; Smith, Z.D.; Meissner, A.; et al. Highly Efficient Reprogramming to Pluripotency and Directed Differentiation of Human Cells with Synthetic Modified mRNA. Cell Stem Cell 2010, 7, 618-630. [CrossRef] [PubMed]

149. Kim, D.; Kim, C.-H.; Moon, J.-I.; Chung, Y.-G.; Chang, M.-Y.; Han, B.-S.; Ko, S.; Yang, E.; Cha, K.Y.; Lanza, R.; et al. Generation of Human Induced Pluripotent Stem Cells by Direct Delivery of Reprogramming Proteins. Cell Stem Cell 2009, 4, 472-476. [CrossRef]

150. Zhou, H.; Wu, S.; Joo, J.Y.; Zhu, S.; Han, N.W.; Lin, T.; Trauger, S.; Bien, G.; Yao, S.; Zhu, Y.; et al. Generation of Induced Pluripotent Stem Cells Using Recombinant Proteins. Cell Stem Cell 2009, 4, 581. [CrossRef]

151. Ohnuki, M.; Tanabe, K.; Sutou, K.; Teramoto, I.; Sawamura, Y.; Narita, M.; Nakamura, M.; Tokunaga, Y.; Watanabe, A.; Yamanaka, S.; et al. Dynamic regulation of human endogenous retroviruses mediates factor-induced reprogramming and differentiation potential. Proc. Natl. Acad. Sci. USA 2014, 111, 12426-12431. [CrossRef] [PubMed]

152. Kim, K.; Doi, A.; Wen, B.; Ng, K.; Zhao, R.; Cahan, P.; Kim, J.; Aryee, M.J.; Ji, H.; Ehrlich, L.I.R.; et al. Epigenetic memory in induced pluripotent stem cells. Nat. Cell Biol. 2010, 467, 285-290. [CrossRef]

153. Lister, R.; Pelizzola, M.; Kida, Y.S.; Hawkins, R.D.; Nery, J.R.; Hon, G.; Antosiewicz-Bourget, J.; O’Malley, R.; Castanon, R.; Klugman, S.; et al. Hotspots of aberrant epigenomic reprogramming in human induced pluripotent stem cells. Nat. Cell Biol. 2011, 471, 68-73. [CrossRef]

154. Ohi, Y.; Qin, H.; Hong, C.; Blouin, L.; Polo, J.M.; Guo, T.; Qi, Z.; Downey, S.L.; Manos, P.D.; Rossi, D.J.; et al. Incomplete DNA methylation underlies a transcriptional memory of somatic cells in human iPS cells. Nat. Cell Biol. 2011, 13, 541-549. [CrossRef] 
155. Polo, J.M.; Liu, S.; Figueroa, M.E.; Kulalert, W.; Eminli, S.; Tan, K.Y.; Apostolou, E.; Stadtfeld, M.; Li, Y.; Shioda, T.; et al. Cell type of origin influences the molecular and functional properties of mouse induced pluripotent stem cells. Nat. Biotechnol. 2010, 28, 848-855. [CrossRef]

156. Nishino, K.; Toyoda, M.; Yamazaki-Inoue, M.; Fukawatase, Y.; Chikazawa, E.; Sakaguchi, H.; Akutsu, H.; Umezawa, A. DNA methylation dynamics in human induced pluripotent stem cells over time. PLoS Genet. 2011, 7, e1002085. [CrossRef]

157. Kim, K.-Y.; Hysolli, E.; Tanaka, Y.; Wang, B.; Jung, Y.W.; Pan, X.; Weissman, S.M.; Park, I.-H. X Chromosome of Female Cells Shows Dynamic Changes in Status during Human Somatic Cell Reprogramming. Stem Cell Rep. 2014, 2, 896-909. [CrossRef]

158. Silva, S.S.; Rowntree, R.K.; Mekhoubad, S.; Lee, J.T. X-chromosome inactivation and epigenetic fluidity in human embryonic stem cells. Proc. Natl. Acad. Sci. USA 2008, 105, 4820-4825. [CrossRef]

159. Anguera, M.C.; Sadreyev, R.; Zhang, Z.; Szanto, A.; Payer, B.; Sheridan, S.D.; Kwok, S.; Haggarty, S.J.; Sur, I.; Alvarez, J.; et al. Molecular Signatures of Human Induced Pluripotent Stem Cells Highlight Sex Differences and Cancer Genes. Cell Stem Cell 2012, 11, 75-90. [CrossRef]

160. Zhao, T.; Zhang, Z.-N.; Rong, Z.; Xu, Y. Immunogenicity of induced pluripotent stem cells. Nat. Cell Biol. 2011, 474, 212-215. [CrossRef]

161. Zhao, T.; Zhang, Z.-N.; Westenskow, P.D.; Todorova, D.; Hu, Z.; Lin, T.; Rong, Z.; Kim, J.; He, J.; Wang, M.; et al. Humanized Mice Reveal Differential Immunogenicity of Cells Derived from Autologous Induced Pluripotent Stem Cells. Cell Stem Cell 2015, 17, 353-359. [CrossRef] [PubMed]

162. Guha, P.; Morgan, J.W.; Mostoslavsky, G.; Rodrigues, N.P.; Boyd, A.S. Lack of Immune Response to Differentiated Cells Derived from Syngeneic Induced Pluripotent Stem Cells. Cell Stem Cell 2013, 12, 407-412. [CrossRef] [PubMed]

163. Araki, R.; Uda, M.; Hoki, Y.; Sunayama, M.; Nakamura, M.; Ando, S.; Sugiura, M.; Ideno, H.; Shimada, A.; Nifuji, A.; et al. Negligible immunogenicity of terminally differentiated cells derived from induced pluripotent or embryonic stem cells. Nat. Cell Biol. 2013, 494, 100-104. [CrossRef]

164. Strnadel, J.; Carromeu, C.; Bardy, C.; Navarro, M.; Platoshyn, O.; Glud, A.N.; Marsala, S.; Kafka, J.; Miyanohara, A.; Kato, T.; et al. Survival of syngeneic and allogeneic iPSC-derived neural precursors after spinal grafting in minipigs. Sci. Transl. Med. 2018, 10, eaam6651. [CrossRef]

165. López, M.M.; Valenzuela, J.E.; Álvarez, F.C.; López-Álvarez, M.R.; Cecilia, G.S.; Paricio, P.P. Long-term problems related to immunosuppression. Transpl. Immunol. 2006, 17, 31-35. [CrossRef]

166. Li, L.; Baroja, M.L.; Majumdar, A.; Chadwick, K.; Rouleau, A.; Gallacher, L.; Ferber, I.; Lebkowski, J.; Martin, T.; Madrenas, J.; et al. Human Embryonic Stem Cells Possess Immune-Privileged Properties. Stem Cells 2004, 22, 448-456. [CrossRef]

167. Drukker, M.; Katchman, H.; Katz, G.; Friedman, S.E.-T.; Shezen, E.; Hornstein, E.; Mandelboim, O.; Reisner, Y.; Benvenisty, N. Human Embryonic Stem Cells and Their Differentiated Derivatives Are Less Susceptible to Immune Rejection Than Adult Cells. Stem Cells 2006, 24, 221-229. [CrossRef]

168. Perez-Cunningham, J.; Ames, E.; Smith, R.C.; Peter, A.K.; Naidu, R.; Nolta, J.A.; Murphy, W.J. Natural Killer Cell Subsets Differentially Reject Embryonic Stem Cells Based on Licensing. Transplantation 2014, 97, 992-998. [CrossRef]

169. Sheldon, S.; Poulton, K.; Philip, H.; Marlene, R. HLA Typing and Its Influence on Organ Transplantation. Transplant. Immunol. 2006, 333, 157-174. [CrossRef]

170. Lee, S.; Huh, J.Y.; Turner, D.M.; Lee, S.; Robinson, J.; Stein, J.E.; Shim, S.H.; Hong, C.P.; Kang, M.S.; Nakagawa, M.; et al. Repurposing the Cord Blood Bank for Haplobanking of HLA-Homozygous iPSCs and Their Usefulness to Multiple Populations. Stem Cells 2018, 36, 1552-1566. [CrossRef]

171. Umekage, M.; Sato, Y.; Takasu, N. Overview: An iPS cell stock at CiRA. Inflamm. Regen. 2019, 39, 1-5. [CrossRef]

172. Gourraud, P.-A.; Gilson, L.; Girard, M.; Peschanski, M. The Role of Human Leukocyte Antigen Matching in the Development of Multiethnic "Haplobank" of Induced Pluripotent Stem Cell Lines. Stem Cells 2012, 30, 180-186. [CrossRef] [PubMed]

173. Xu, H.; Wang, B.; Ono, M.; Kagita, A.; Fujii, K.; Sasakawa, N.; Ueda, T.; Gee, P.; Nishikawa, M.; Nomura, M.; et al. Targeted Disruption of HLA Genes via CRISPR-Cas9 Generates iPSCs with Enhanced Immune Compatibility. Cell Stem Cell 2019, 24, 566-578.e7. [CrossRef] [PubMed] 
174. Morizane, A.; Kikuchi, T.; Hayashi, T.; Mizuma, H.; Takara, S.; Doi, H.; Mawatari, A.; Glasser, M.F.; Shiina, T.; Ishigaki, H.; et al. MHC matching improves engraftment of iPSC-derived neurons in non-human primates. Nat. Commun. 2017, 8,1-12. [CrossRef]

175. Badin, R.A.; Bugi, A.; Williams, S.; Vadori, M.; Michael, M.; Jan, C.; Nassi, A.; Lecourtois, S.; Blancher, A.; Cozzi, E.; et al. MHC matching fails to prevent long-term rejection of iPSC-derived neurons in non-human primates. Nat. Commun. 2019, 10, 1-12. [CrossRef]

176. Kawamura, T.; Miyagawa, S.; Fukushima, S.; Maeda, A.; Kashiyama, N.; Kawamura, A.; Miki, K.; Okita, K.; Yoshida, Y.; Shiina, T.; et al. Cardiomyocytes Derived from MHC-Homozygous Induced Pluripotent Stem Cells Exhibit Reduced Allogeneic Immunogenicity in MHC-Matched Non-human Primates. Stem Cell Rep. 2016, 6, 312-320. [CrossRef]

177. Deuse, T.; Hu, X.; Gravina, A.; Wang, D.; Tediashvili, G.; De, C.; Thayer, W.O.; Wahl, A.; Garcia, J.V.; Reichenspurner, H.; et al. Hypoimmunogenic derivatives of induced pluripotent stem cells evade immune rejection in fully immunocompetent allogeneic recipients. Nat. Biotechnol. 2019, 37, 252-258. [CrossRef]

178. Jang, Y.; Choi, J.; Park, N.; Kang, J.; Kim, M.; Kim, Y.; Ju, J.H. Development of immunocompatible pluripotent stem cells via CRISPR-based human leukocyte antigen engineering. Exp. Mol. Med. 2019, 51, 1-11. [CrossRef]

179. Han, X.; Wang, M.; Duan, S.; Franco, P.J.; Kenty, J.H.-R.; Hedrick, P.; Xia, Y.; Allen, A.; Ferreira, L.M.R.; Strominger, J.L.; et al. Generation of hypoimmunogenic human pluripotent stem cells. Proc. Natl. Acad. Sci. USA 2019, 116, 10441-10446. [CrossRef]

180. Gornalusse, G.G.; Hirata, R.K.; Funk, S.E.; Riolobos, L.; Lopes, V.S.; Manske, G.; Prunkard, D.; Colunga, A.G.; Hanafi, L.-A.; O Clegg, V.S.L.D.; et al. HLA-E-expressing pluripotent stem cells escape allogeneic responses and lysis by NK cells. Nat. Biotechnol. 2017, 35, 765-772. [CrossRef]

181. Sorrells, S.F.; Paredes, M.F.; Cebrian-Silla, A.; Sandoval, K.; Qi, D.; Kelley, K.W.; James, D.; Mayer, S.; Chang, J.; Auguste, K.I.; et al. Human hippocampal neurogenesis drops sharply in children to undetectable levels in adults. Nat. Cell Biol. 2018, 555, 377-381. [CrossRef]

182. Tobin, M.K.; Musaraca, K.; Disouky, A.; Shetti, A.; Bheri, A.; Honer, W.G.; Kim, N.; Dawe, R.J.; Bennett, D.A.; Arfanakis, K.; et al. Human Hippocampal Neurogenesis Persists in Aged Adults and Alzheimer's Disease Patients. Cell Stem Cell 2019, 24, 974-982.e3. [CrossRef] [PubMed]

183. Moreno-Jiménez, E.P.; Flor-García, M.; Terreros-Roncal, J.; Rábano, A.; Cafini, F.; Pallas-Bazarra, N.; Ávila, J.; Llorens-Martín, M. Adult hippocampal neurogenesis is abundant in neurologically healthy subjects and drops sharply in patients with Alzheimer's disease. Nat. Med. 2019, 25, 554-560. [CrossRef] [PubMed]

184. Silver, J.; Schwab, M.E.; Popovich, P.G. Central Nervous System Regenerative Failure: Role of Oligodendrocytes, Astrocytes, and Microglia. Cold Spring Harb. Perspect. Biol. 2014, 7, a020602. [CrossRef] [PubMed]

185. Kempf, A.; Schwab, M.E. Nogo-A Represses Anatomical and Synaptic Plasticity in the Central Nervous System. Physiology 2013, 28, 151-163. [CrossRef]

186. Gonzenbach, R.R.; Zoerner, B.; Schnell, L.; Weinmann, O.; Mir, A.K.; Schwab, M.E. Delayed Anti-Nogo-A Antibody Application after Spinal Cord Injury Shows Progressive Loss of Responsiveness. J. Neurotrauma 2012, 29, 567-578. [CrossRef]

187. Zhang, Y.-F.; Wang, J.-W.; Yang, J.-F.; Ma, Y.; Hua, Z.; Guo, Y.; Gu, X.-L. Nogo-A expression dynamically varies after spinal cord injury. Neural Regen. Res. 2015, 10, 225-229. [CrossRef]

188. Liebscher, T.; Schnell, L.; Schnell, D.; Scholl, J.; Schneider, R.; Gullo, M.; Fouad, K.; Mir, A.; Rausch, M.; Kindler, D.; et al. Nogo-A antibody improves regeneration and locomotion of spinal cord-injured rats. Ann. Neurol. 2005, 58, 706-719. [CrossRef]

189. Popovich, P.G.; Guan, Z.; Wei, P.; Huitinga, I.; Van Rooijen, N.; Stokes, B.T. Depletion of Hematogenous Macrophages Promotes Partial Hindlimb Recovery and Neuroanatomical Repair after Experimental Spinal Cord Injury. Exp. Neurol. 1999, 158, 351-365. [CrossRef]

190. Stirling, D.P.; Khodarahmi, K.; Liu, J.; McPhail, L.T.; McBride, C.B.; Steeves, J.D.; Ramer, M.S.; Tetzlaff, W. Minocycline Treatment Reduces Delayed Oligodendrocyte Death, Attenuates Axonal Dieback, and Improves Functional Outcome after Spinal Cord Injury. J. Neurosci. 2004, 24, 2182-2190. [CrossRef]

191. Gensel, J.C.; Nakamura, S.; Guan, Z.; Van Rooijen, N.; Ankeny, D.P.; Popovich, P.G. Macrophages promote axon regeneration with concurrent neurotoxicity. J. Neurosci. 2009, 29, 3956-3968. [CrossRef] [PubMed]

192. Stirling, D.P.; Cummins, K.; Mishra, M.; Teo, W.; Yong, V.W.; Stys, P. Toll-like receptor 2-mediated alternative activation of microglia is protective after spinal cord injury. Brain 2014, 137, 707-723. [CrossRef] 
193. Davies, A.J.; Kim, H.W.; Gonzalez-Cano, R.; Choi, J.; Back, S.K.; Roh, S.E.; Johnson, E.; Gabriac, M.; Kim, M.-S.; Lee, J.; et al. Natural Killer Cells Degenerate Intact Sensory Afferents following Nerve Injury. Cell 2019, 176, 716-728.e18. [CrossRef] [PubMed]

194. Padi, S.S.; Kulkarni, S.K. Minocycline prevents the development of neuropathic pain, but not acute pain: Possible anti-inflammatory and antioxidant mechanisms. Eur. J. Pharmacol. 2008, 601, 79-87. [CrossRef]

195. Ohtake, Y.; Li, S. Molecular mechanisms of scar-sourced axon growth inhibitors. Brain Res. 2015, 1619, $22-35$. [CrossRef] [PubMed]

196. Monnier, P.P.; Sierra, A.; Schwab, J.M.; Henke-Fahle, S.; Mueller, B.K. The Rho/ROCK pathway mediates neurite growth-inhibitory activity associated with the chondroitin sulfate proteoglycans of the CNS glial scar. Mol. Cell. Neurosci. 2003, 22, 319-330. [CrossRef] [PubMed]

197. Bradbury, E.J.; Moon, L.D.F.; Popat, R.J.; King, V.R.; Bennett, G.S.; Patel, P.N.; Fawcett, J.W.; McMahon, S.B. Chondroitinase ABC promotes functional recovery after spinal cord injury. Nat. Cell Biol. 2002, 416, 636-640. [CrossRef]

198. Barritt, A.W.; Davies, M.; Marchand, F.; Hartley, R.; Grist, J.; Yip, P.; McMahon, S.B.; Bradbury, E.J. Chondroitinase ABC Promotes Sprouting of Intact and Injured Spinal Systems after Spinal Cord Injury. J. Neurosci. 2006, 26, 10856-10867. [CrossRef]

199. Alilain, W.J.; Horn, K.P.; Hu, H.; Dick, T.E.; Silver, J. Functional regeneration of respiratory pathways after spinal cord injury. Nat. Cell Biol. 2011, 475, 196-200. [CrossRef]

200. Yu, P.; Jin, J.; Tilve, S.; Huang, Z.; Zhou, L.; Geller, H.M. Effect of chondroitin sulfate proteoglycans on neuronal cell adhesion, spreading and neurite growth in culture. Neural Regen. Res. 2018, 13, 289-297. [CrossRef]

201. Tang, H.-B.; Jiang, X.-J.; Wang, C.; Liu, S.-C. S1P/S1PR3 signaling mediated proliferation of pericytes via Ras/pERK pathway and CAY10444 had beneficial effects on spinal cord injury. Biochem. Biophys. Res. Commun. 2018, 498, 830-836. [CrossRef] [PubMed]

202. Sabelström, H.; Stenudd, M.; Réu, P.; Dias, D.O.; Elfineh, M.; Zdunek, S.; Damberg, P.; Göritz, C.; Frisén, J. Resident Neural Stem Cells Restrict Tissue Damage and Neuronal Loss After Spinal Cord Injury in Mice. Science 2013, 342, 637-640. [CrossRef]

203. Anderson, M.A.; Burda, J.E.; Ren, Y.; Ao, Y.; O'Shea, T.M.; Kawaguchi, R.; Coppola, R.K.G.; Khakh, B.S.; Deming, T.J.; Sofroniew, M.V. Astrocyte scar formation aids central nervous system axon regeneration. Nat. Cell Biol. 2016, 532, 195-200. [CrossRef]

204. Haindl, M.T.; Köck, U.; Zeitelhofer-Adzemovic, M.; Fazekas, F.; Hochmeister, S. The formation of a glial scar does not prohibit remyelination in an animal model of multiple sclerosis. Glia 2018, 67, 467-481. [CrossRef] [PubMed]

Publisher's Note: MDPI stays neutral with regard to jurisdictional claims in published maps and institutional affiliations.

(C) 2020 by the authors. Licensee MDPI, Basel, Switzerland. This article is an open access article distributed under the terms and conditions of the Creative Commons Attribution (CC BY) license (http://creativecommons.org/licenses/by/4.0/). 